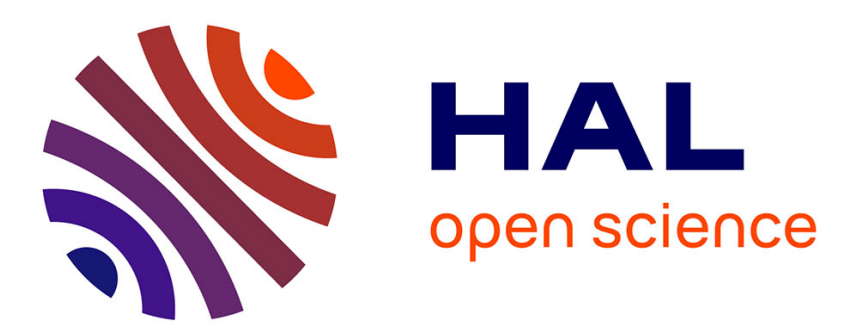

\title{
Degradation by Hydrogen Peroxide of Metal-Nitrogen-Carbon Catalysts for Oxygen Reduction
}

Vincent Goellner, Vanessa Armel, Andrea Zitolo, Emiliano Fonda, Frédéric

Jaouen

\section{- To cite this version:}

Vincent Goellner, Vanessa Armel, Andrea Zitolo, Emiliano Fonda, Frédéric Jaouen. Degradation by Hydrogen Peroxide of Metal-Nitrogen-Carbon Catalysts for Oxygen Reduction. Journal of The Electrochemical Society, 2015, 162 (6), pp.H403-H404. 10.1149/2.1091506jes . hal-01174287

\section{HAL Id: hal-01174287 \\ https://hal.science/hal-01174287}

Submitted on 8 Jul 2015

HAL is a multi-disciplinary open access archive for the deposit and dissemination of scientific research documents, whether they are published or not. The documents may come from teaching and research institutions in France or abroad, or from public or private research centers.
L'archive ouverte pluridisciplinaire HAL, est destinée au dépôt et à la diffusion de documents scientifiques de niveau recherche, publiés ou non, émanant des établissements d'enseignement et de recherche français ou étrangers, des laboratoires publics ou privés. 


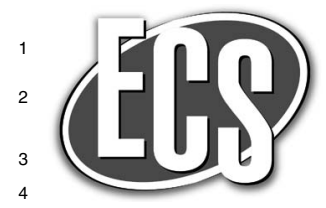

\title{
Degradation by Hydrogen Peroxide of Metal-Nitrogen-Carbon Catalysts for Oxygen Reduction
}

\author{
Vincent Goellner, ${ }^{\text {a,* }}$ Vanessa Armel,,${ }^{a, *}$ Andrea Zitolo, ${ }^{\text {b Emiliano Fonda, }}{ }^{\mathrm{b}}$ \\ and Frédéric Jaouen ${ }^{\mathrm{a}, * *, \mathrm{z}}$
}

\author{
a Institut Charles Gerhardt Montpellier, UMR CNRS 5253, Agrégats, Interfaces et Matériaux pour l'Energie, \\ Université Montpellier, 34095 Montpellier cedex 5, France \\ ${ }^{b}$ Synchrotron SOLEIL, L'Orme des Merisiers Saint-Aubin - BP 48, 91192 Gif-sur-Yvette, France
}

\begin{abstract}
Fe-N-C and Co-N-C materials are promising catalysts for reducing oxygen in fuel cells. The degradation of such catalysts induced by $\mathrm{H}_{2} \mathrm{O}_{2}$ was investigated by contacting them ex situ with various amounts of $\mathrm{H}_{2} \mathrm{O}_{2}$. The degradation increased with increasing amounts of $\mathrm{H}_{2} \mathrm{O}_{2}$. The effect was most severe for Cr-N-C followed by Fe-N-C and last by Co-N-C. Treatment with $\mathrm{H}_{2} \mathrm{O}_{2}$ leads to diminished oxygen reduction activity at high potential and/or reduced transport properties at high current density in fuel cell. From spectroscopic characterisation, it was found that 66 and $80 \%$ of the $\mathrm{CoN}_{\mathrm{x}} \mathrm{C}_{\mathrm{y}}$ and $\mathrm{FeN}_{\mathrm{x}} \mathrm{C}_{\mathrm{y}}$ moieties present in pristine catalysts survived the extensive $\mathrm{H}_{2} \mathrm{O}_{2}$ treatment, respectively. In parallel, the activity for oxygen reduction was divided by ca 6-10 for Fe-N-C and by ca 3 for Co-N-C. The results suggest that the main degradation mechanism in fuel cell for such catalysts is due to a chemical reaction with $\mathrm{H}_{2} \mathrm{O}_{2}$ that is generated during operation. The super-proportional decrease of the oxygen reduction activity with loss of $\mathrm{FeN}_{\mathrm{x}} \mathrm{C}_{\mathrm{y}}$ and $\mathrm{CoN}_{\mathrm{x}} \mathrm{C}_{\mathrm{y}}$ moieties suggests either that only a small fraction of such moieties are initially located on the top surface, or that their turnover frequency for oxygen reduction was drastically reduced due to surface oxidation by $\mathrm{H}_{2} \mathrm{O}_{2}$.

(C) The Author(s) 2015. Published by ECS. This is an open access article distributed under the terms of the Creative Commons Attribution Non-Commercial No Derivatives 4.0 License (CC BY-NC-ND, http://creativecommons.org/licenses/by-nc-nd/4.0/), which permits non-commercial reuse, distribution, and reproduction in any medium, provided the original work is not changed in any way and is properly cited. For permission for commercial reuse, please email: oa@electrochem.org. [DOI: 10.1149/2.1091506jes] All rights reserved.
\end{abstract}

Manuscript submitted February 5, 2015; revised manuscript received March 11, 2015. Published 00 0,2015. This was Paper 1589 presented at the San Francisco, California, Meeting of the Society, October 27-November 1, 2013.

Electrochemical energy conversion devices are expected to play an increasing role for stationary and transportation applications as well as for reversible energy storage. Among the various applications already in use or contemplated for electrochemical devices, the transportation sector is the most demanding in terms of energy density, power density and cost. 1 Driving a full-size car over $100 \mathrm{~km}$ requires ca $13 \mathrm{kWh}$ of mechanical energy. ${ }^{2}$ While batteries are more efficient than fuel cells, the higher energy density of $\mathrm{H}_{2} /$ air fuel cells relative to the lithiumion battery $\left(1.8 \mathrm{kWh}\right.$ per $\mathrm{kg}$ of $\mathrm{H}_{2}$-reservoir at 690 bars; compared to $0.2 \mathrm{kWh}$ per $\mathrm{kg}$ of Li-ion battery pack) is critical for designing a system that can propel a car over $500 \mathrm{~km}$ without refuelling or recharging. ${ }^{2-3}$ Hence, the polymer electrolyte membrane fuel cell (PEMFC) is today the most promising electrochemical device for replacing internal combustion engines, with uncompromised driving range and power density. ${ }^{3}$ Mid-term remaining challenges for PEMFCs are increased durability and reduced cost, while a longer-term challenge is the replacement of the rare and expensive platinum element by catalysts based on Earth-abundant metals. ${ }^{1,4-5}$ Today, ca $80-90 \%$ of the mass of Pt in a PEMFC stack is placed at the cathode due to the sluggish oxygen reduction reaction (ORR) compared to fast hydrogen oxidation at the anode. Based on projections for mass production, Pt-based catalysts in today's PEMFC technology are expected to account for ca $50 \%$ of the material's cost of a fuel cell stack. ${ }^{4,6}$ Significantly reducing the Pt loading in cathodes or eliminating the platinum metal altogether from ORR catalysts are two possible approaches to tackle this cost problem.

While the concept of ORR catalysis by materials or molecules comprising $\mathrm{Fe}$ or $\mathrm{Co}$, nitrogen and carbon elements is known since $1964,{ }^{7}$ breakthroughs in the ORR activity and fuel cell performance that were necessary to seriously consider $\mathrm{Fe}(\mathrm{Co})-\mathrm{N}-\mathrm{C}$ catalysts as potential substitutes to platinum in the acidic environment of PEMFCs were reported only after $2008 .^{2,8-14}$ While major advances in the ORR activity and power density of PEMFC comprising $\mathrm{Fe}(\mathrm{Co})-\mathrm{N}-\mathrm{C}$ based cathodes have been reported, the next grand scientific challenges are i) improved understanding of the structure of the active sites and

\footnotetext{
*Electrochemical Society Student Member.

**Electrochemical Society Active Member.

${ }^{\mathrm{z} E-m a i l: ~ f r e d e r i c . j a o u e n @ u n i v-m o n t p 2 . f r ~}$
}

ii) improved understanding of the degradation mechanisms. Depending on the latter, mitigation approaches might be very different: i) system-based solutions to avoid the transient high-potential polarization during start-up and shutdown, ii) catalyst-based approaches in order to avoid the formation of $\mathrm{H}_{2} \mathrm{O}_{2}$ during ORR or to endow the catalysts with a higher graphitic character, iii) novel cathode designs in order to stabilize its electrical, hydrophilic and diffusion properties. A restricted number of studies have focused on the degradation mechanisms of $\mathrm{Fe}(\mathrm{Co})-\mathrm{N}-\mathrm{C}$ catalysts. ${ }^{15-28} \mathrm{Fe}-\mathrm{N}-\mathrm{C}$ catalysts pyrolyzed in $\mathrm{NH}_{3}$ have shown the highest initial activity and power performance thus far, but degrade very quickly in PEMFC, mostly due to a protonation and anion-binding effect of highly-basic surface $\mathrm{N}$-groups that are characteristic of $\mathrm{NH}_{3}$ pyrolysis. ${ }^{16} \mathrm{Fe}(\mathrm{Co})-\mathrm{N}-\mathrm{C}$ catalysts synthesized at high temperature in inert gas are initially less active but are more stable in PEMFC. ${ }^{8-10,15,26}$ Disentangling the various degradation phenomena of $\mathrm{Fe}(\mathrm{Co})-\mathrm{N}-\mathrm{C}$ cathodes occurring during PEMFC operation is complex. Water flooding, changes of the hydrophilic properties of the cathode, loss of a fraction of the active sites through dissolution or via oxidative attacks generated by either the cathode potential, $\mathrm{H}_{2} \mathrm{O}_{2}$ or radical oxygen species (ROS) formed between $\mathrm{H}_{2} \mathrm{O}_{2}$ and the transition-metal-based active sites may all account to some degree for the overall decline of the cathode performance with time. In a first attempt to disentangle these phenomena, we recently investigated on a well-defined Fe-N-C catalyst the degradation incurred by high-voltage cycling. ${ }^{21}$ This phenomenon is the least complex one to separately investigate from other degradation routes since it is not linked to the ORR. It was concluded that the $\mathrm{FeN}_{\mathrm{x}} \mathrm{C}_{\mathrm{y}}$ moieties initially present in the Fe-N-C catalyst were not immediately destroyed after a polarization up to 1.4-1.5 V vs. RHE. However, bulk oxidation of the carbon matrix in which these active sites are embedded ultimately lead to the massive dissolution of $\mathrm{FeN}_{\mathrm{x}} \mathrm{C}_{\mathrm{y}}$ moieties. In addition, increased electric resistance of the cathode layer after high potential cycling also contributed to the decline of the cathode performance. ${ }^{21}$ Due to the integration of $\mathrm{Fe}(\mathrm{Co}) \mathrm{N}_{\mathrm{x}} \mathrm{C}_{\mathrm{y}}$ moieties at the edge of graphene sheets or within the sheets, these materials are intrinsically more prone to degradation when subjected to high electric potential than $\mathrm{Pt} / \mathrm{C}$ catalysts. More graphitic matrices may be resorted to for synthesizing $\mathrm{Fe}(\mathrm{Co})-\mathrm{N}-\mathrm{C}$ catalysts. However, it is notoriously difficult to achieve a high density of $\mathrm{Fe}(\mathrm{Co}) \mathrm{N}_{\mathrm{x}} \mathrm{C}_{\mathrm{y}}$ moieties in highly graphitic substrates via pyrolysis. ${ }^{23,29}$ Mitigation of the degradation induced by high-voltage 
102 on $\mathrm{Fe}(\mathrm{Co})-\mathrm{N}-\mathrm{C}$ catalysts should therefore be most effective by focus103 ing on the causes of the high-voltage transients, namely i) the purging 104 of uncombusted $\mathrm{H}_{2}$ at the anode with air and ii) the non-selectivity of 105 platinum for hydrogen oxidation. ${ }^{30-32}$

The present work focuses on the oxidative attack of Me-N-C 107 catalysts by minute amount of $\mathrm{H}_{2} \mathrm{O}_{2}$ that is produced due to the 108 incomplete electro-reduction of $\mathrm{O}_{2}$ to $\mathrm{H}_{2} \mathrm{O}$ during fuel cell operation. 109 This degradation mechanism can probably not be dealt with at a sys110 tem level and is therefore an inescapable issue for Me-N-C catalysts. 11 While the $\% \mathrm{H}_{2} \mathrm{O}_{2}$ produced during ORR is often not much higher 12 on $\mathrm{Fe}(\mathrm{Co})-\mathrm{N}-\mathrm{C}$ than on $\mathrm{Pt} / \mathrm{C}$ catalysts, ${ }^{25-27,33-34}$ the residence time 13 of $\mathrm{H}_{2} \mathrm{O}_{2}$ in the electrode may be longer with $\mathrm{Fe}(\mathrm{Co})-\mathrm{N}-\mathrm{C}$ catalysts 14 due to their extremely poor activity for the electro-reduction of $\mathrm{H}_{2} \mathrm{O}_{2}$ 15 to $\mathrm{H}_{2} \mathrm{O},{ }^{33,35}$ and poor activity for the chemical disproportionation of $16 \mathrm{H}_{2} \mathrm{O}_{2} \cdot{ }^{27,33,35-36}$ Chemical disproportionation of $\mathrm{H}_{2} \mathrm{O}_{2}$ is ca two orders 17 of magnitude faster at high $\mathrm{pH}$ for such catalysts, ${ }^{36}$ highlighting the 18 possibility to recycle $\mathrm{H}_{2} \mathrm{O}_{2}$ at high $\mathrm{pH}$ but impossibility to do so at 19 low $\mathrm{pH}$. In contrast, platinum is an excellent catalyst for both the 20 four-electron reduction of $\mathrm{O}_{2}$ to $\mathrm{H}_{2} \mathrm{O}$ and the two-electron reduction 21 of $\mathrm{H}_{2} \mathrm{O}_{2}$ to $\mathrm{H}_{2} \mathrm{O} .{ }^{33,37}$ The important difference between the durability 22 of $\mathrm{Pt} / \mathrm{C}$ and $\mathrm{Fe}(\mathrm{Co})-\mathrm{N}-\mathrm{C}$ catalysts in PEMFC may thus stem from their 23 different reactivity toward $\mathrm{H}_{2} \mathrm{O}_{2}$. Moreover, chemical disproportion24 ation of $\mathrm{H}_{2} \mathrm{O}_{2}$ on $\mathrm{Fe}(\mathrm{Co})-\mathrm{N}-\mathrm{C}$ catalysts via Fenton chemistry might 125 produce a significant amount of radical oxygen species (ROS). ${ }^{38-40}$ ${ }_{26}$ While suspected, the role of $\mathrm{H}_{2} \mathrm{O}_{2}$ in the degradation of $\mathrm{Fe}(\mathrm{Co})-\mathrm{N}-\mathrm{C}$ 27 based cathodes during steady-state operation of a PEMFC has not 28 yet been investigated in depth. Early work by Wiesener showed that 29 addition for every $100 \mathrm{~h}$ of a given aliquot of $\mathrm{H}_{2} \mathrm{O}_{2}$ to the electrolyte ${ }_{30}$ lead to a faster degradation of a Co-N-C catalyst. ${ }^{41}$ Ex situ chemical 31 degradation of $\mathrm{Fe}-\mathrm{N}-\mathrm{C}$ catalysts with $\mathrm{H}_{2} \mathrm{O}_{2}$ was investigated in 2003 ${ }_{32}$ by Lefèvre. ${ }^{25} \mathrm{~A}$ series of catalysts were immersed in $\mathrm{H}_{2} \mathrm{O}_{2}$ solutions of 33 various concentrations. The ORR activities measured with a rotating34 disk electrode (RDE) were shown to have strongly decreased. More 35 recently, Zelenay's group applied a different ex situ $\mathrm{H}_{2} \mathrm{O}_{2}$ treatment, ${ }_{36}$ keeping the $\mathrm{H}_{2} \mathrm{O}_{2}$ concentration fixed but varying the duration of im${ }_{37}$ mersion of the catalyst. ${ }^{26}$ In addition to measuring the ORR activity 38 in RDE before and after the treatments, also the elemental compo39 sition was determined by X-ray photoelectron spectroscopy (XPS). 40 A comprehensive understanding of the degradation mechanism of ${ }_{41}$ Me-N-C catalysts upon contact with $\mathrm{H}_{2} \mathrm{O}_{2}$ solution is however still 142 lacking, especially regarding spectroscopic changes of the transition 43 metal coordination.

144 In the present work, we synthesized a Fe-N-C, a Co-N-C and a $15 \mathrm{Cr}-\mathrm{N}-\mathrm{C}$ catalyst and contacted them with various amounts of $\mathrm{H}_{2} \mathrm{O}_{2}$ 46 corresponding to ratios of mol $\mathrm{H}_{2} \mathrm{O}_{2}$ per mass of catalyst ranging 47 over ca two orders of magnitudes. The ORR activities of the catalysts 48 before and after $\mathrm{H}_{2} \mathrm{O}_{2}$ treatment were determined with $\mathrm{RDE}$ and in 49 PEMFC. The pristine and treated materials were characterized with 50 X-ray diffraction, X-ray absorption spectroscopy, X-ray photoelectron 51 spectroscopy and, for Fe-N-C, with ${ }^{57} \mathrm{Fe}$ Mössbauer spectroscopy.

152

153 154 ballmilling approach from a $\mathrm{Zn}$ (II) zeolitic imidazolate framework $155\left(\mathrm{ZnN}_{4} \mathrm{C}_{8} \mathrm{H}_{12}\right.$, Basolite $\mathrm{Z} 1200$ from BASF, labelled ZIF-8), $\mathrm{Fe}(\mathrm{II})$ ac156 etate (Fe(II)Ac), $\mathrm{Co}$ (II)Ac, $\mathrm{Cr}$ (II)Ac and 1,10-phenanthroline. The $157 \mathrm{Fe}-\mathrm{N}-\mathrm{C}$ and $\mathrm{Co}-\mathrm{N}-\mathrm{C}$ catalysts were synthesized identically: weighed 158 amounts of the dry powders of $\mathrm{Fe}(\mathrm{II}) \mathrm{Ac}$ (or $\mathrm{Co}$ (II)Ac), phenanthroline 159 and ZIF-8 were poured into a $\mathrm{ZrO}_{2}$ crucible. Then, 100 zirconium160 oxide balls of $5 \mathrm{~mm}$ diameter were added and the crucible was sealed 161 under air and placed in a planetary ball-miller (FRITSCH Pulverisette 1627 Premium) to undergo 4 cycles of $30 \mathrm{~min}$ of ballmilling at $400 \mathrm{rpm}$. ${ }_{163}$ The resulting catalyst precursor was pyrolyzed at $1050^{\circ} \mathrm{C}$ in $\mathrm{Ar}$ for $1641 \mathrm{~h}$. The catalyst precursors contained $1 \mathrm{wt} \%$ of metal and the mass 165 ratio of phenanthroline to ZIF-8 was 20/80. ${ }^{9,21}$ The mass loss during 166 pyrolysis was $60-65 \mathrm{wt} \%$, leading to $\mathrm{Fe}$ and Co contents of 2.5-2.9 $167 \mathrm{wt} \%$. The catalyst precursor for $\mathrm{Cr}-\mathrm{N}-\mathrm{C}$ was prepared identically, but 168 the pyrolysis was performed under flowing $\mathrm{NH}_{3}$ at $950^{\circ} \mathrm{C}$ for $15 \mathrm{~min}$.

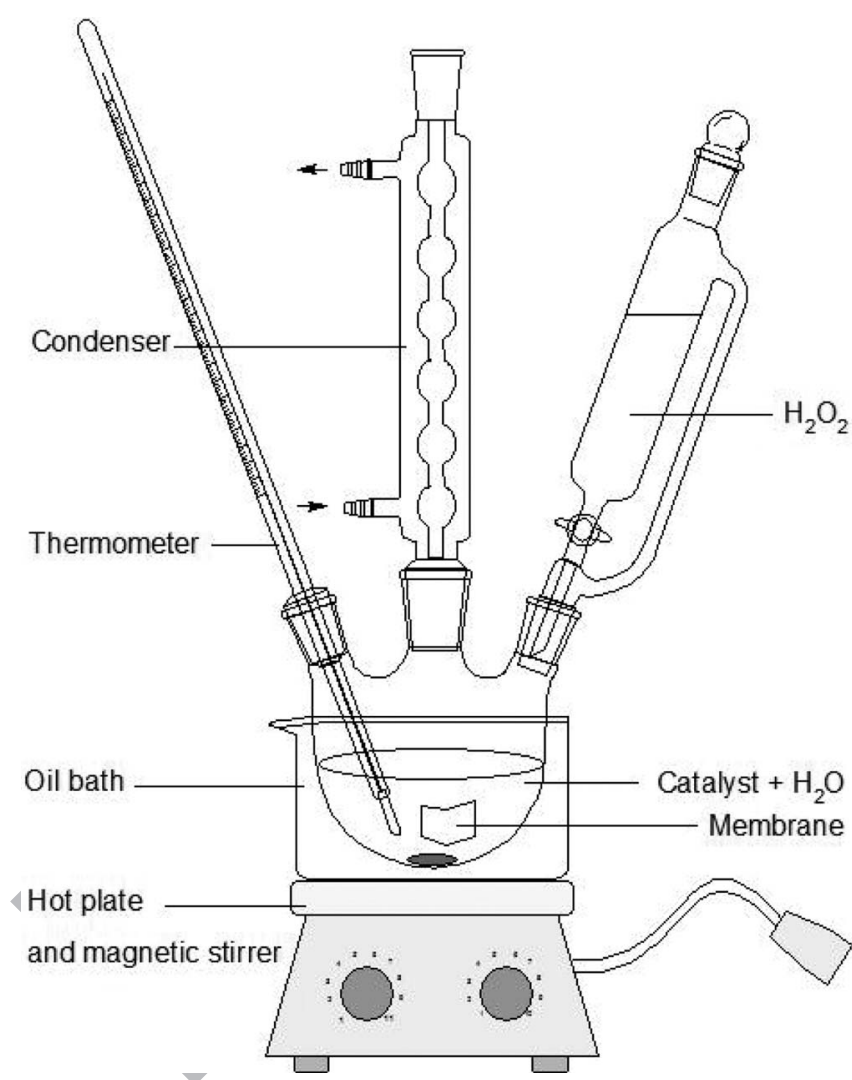

Figure 1. Scheme of the experimental setup used for ex situ $\mathrm{H}_{2} \mathrm{O}_{2}$ degradation.

When pyrolyzed in Ar, the initial ORR activity of $\mathrm{Cr}-\mathrm{N}-\mathrm{C}$ was too 169 low to be of interest. The resulting Cr-based catalyst was then acid 170 washed in a $\mathrm{pH} 1$ sulphuric acid solution and copiously washed with 171 de-ionized water. The acid washing was applied only to Cr-N-C in or- 172 der to compare its ORR activity to the Ar-pyrolyzed Fe- and Co-N-C 173 catalysts. It is known that pyrolysis in $\mathrm{NH}_{3}$ leads to a higher initial 174 ORR activity, mostly due to the presence of highly basic surface N- 175 groups. ${ }^{16}$ This promotion of ORR activity due to the high basicity of 176 $\mathrm{N}$-groups is usually suppressed after an acid wash, which protonates $\quad 177$ basic N-groups followed by anion adsorption. The mass loss during 178 pyrolysis for the Cr-based catalyst precursor was 85-90 wt\%, leading 179 to $8-10 \mathrm{wt} \% \mathrm{Cr}$ in $\mathrm{Cr}-\mathrm{N}-\mathrm{C}$.

Chemical treatment with hydrogen peroxide. - $100 \mathrm{mg}$ of catalyst 181 was dispersed and stirred in $(500-\mathrm{X}) \mathrm{ml}$ of deionized water heated 182 to $80^{\circ} \mathrm{C}$ under reflux. A piece of Nafion 117 membrane with area $4.84 \quad 183$ $\mathrm{cm}^{2}$ was also immersed in solution in order to serve as an indicator ${ }_{184}$ for ROS. The scalar X represent the total volume of $30 \mathrm{wt} \% \mathrm{H}_{2} \mathrm{O}_{2} \quad 185$ solution that was added to reach the desired number of mol $\mathrm{H}_{2} \mathrm{O}_{2} \quad{ }_{186}$ per mg of catalyst. This volume was systematically divided in four 187 aliquots of X/4 ml, each aliquot being added with a one hour time 188 interval. Once the total desired volume of $\mathrm{H}_{2} \mathrm{O}_{2}$ had been added, the 189 solution was stirred for $24 \mathrm{~h}$ at $80^{\circ} \mathrm{C}$ under reflux and then allowed to 190 cool down to room temperature. The entire experimental setup can be 191 visualized in Fig. 1. For example, in order to reach a ratio of $10^{-2} \mathrm{~mol} 192$ $\mathrm{H}_{2} \mathrm{O}_{2}$ per mg of catalyst, four aliquots of $25 \mathrm{ml}$ each of $30 \mathrm{wt} \% \mathrm{H}_{2} \mathrm{O}_{2} \quad 193$ solution were added every hour to a solution initially containing $100 \quad 194$ $\mathrm{mg}$ of catalyst dispersed in 500- $(4 \times 25) \mathrm{ml}$ of deionized water. In 195 the present study, the ratio of $\mathrm{mol} \mathrm{H}_{2} \mathrm{O}_{2}$ per $\mathrm{mg}$ catalyst was spanned 196 from $5 \times 10^{-4}$ to $2 \times 10^{-2}$ by changing the cumulative volume of $30 \quad 197$ wt $\% \mathrm{H}_{2} \mathrm{O}_{2}$ from 5 to $200 \mathrm{ml}$. Each $\mathrm{H}_{2} \mathrm{O}_{2}$ treatment was terminated 198 with a one hour sonication of the solution to solubilize fluoride ions 199 originating from membrane degradation. The Nafion membrane piece 200 
201 was removed and the solution filtrated using a Büchner setup with 202 a $220 \mathrm{~nm}$ pore-sized filter. The filtrate was stored for fluoride ion 203 analysis while the collected catalyst powder was copiously washed 204 with de-ionized water (ca one litre) before overnight drying at $90^{\circ} \mathrm{C}$. 205 The collected mass of dry catalyst powder was then weighed while 206 the fluoride ion concentration in the filtrate was measured using an ion 207 selective electrode. To avoid any interference of the $\mathrm{pH}$, the electrolyte 208 solution was adjusted with the appropriate ionic strength adjustment 209 buffer (TISAB IV from Sigma-Aldrich) in order to keep the $\mathrm{pH}$ in the 210 range of 5-7. TISAB solution also prevents complexation of fluoride 211 ions with any iron or other trace metals present in solution.

Structural characterization.- Metal K-edge X-ray absorption 213 spectra were recorded at room temperature at SAMBA beamline of 214 Synchrotron SOLEIL. The beamline is equipped with a sagittaly fo215 cusing Si 220 monochromator and two Pd-coated collimating mirrors. 216 The mirrors have been used to remove $\mathrm{X}$-rays harmonics. The catalysts 217 were pelletized as disks of $10 \mathrm{~mm}$ diameter using a 50/50 mass ratio 218 of Teflon powder $(1 \mu \mathrm{m}$ particle size $)$ and catalyst. The spectra were 219 recorded in transmission mode and the energy was calibrated with 220 the corresponding metal foils to correct any change in beam energy 221 during the experiments. All experimental spectra were normalized 222 and analyzed identically with Athena software in order to derive the 223 XANES and Fourier-transform EXAFS spectra. X-ray diffraction was 224 conducted using a PANanalytical X'Pert Pro powder X-ray diffrac225 tometer. XPS spectra were recorded with a Physical Electronics PHI 2265701 spectrometer. Non-monochromatic $\mathrm{Mg} \mathrm{K}_{\alpha} \mathrm{X}$-ray was used as 227 the excitation source. For the pristine and $\mathrm{H}_{2} \mathrm{O}_{2}$-treated $\mathrm{Fe}-\mathrm{N}-\mathrm{C}$ cata228 lysts, ${ }^{57} \mathrm{Fe}$ Mössbauer spectra were measured with a source of ${ }^{57} \mathrm{Co}$ in 229 rhodium. The measurements were performed keeping both the source 230 and the absorber at room temperature. The spectrometer was operated 231 with a triangular velocity waveform, and a $\mathrm{NaI}$ scintillation detector 232 was used for detecting the $\gamma$-rays. Velocity calibration was performed 233 with an $\alpha-\mathrm{Fe}$ foil.

234 Electrochemical characterization.- Electrochemical activity of 235 the catalysts toward the ORR was determined using the RDE tech236 nique. A catalyst ink including $10 \mathrm{mg}$ of catalyst, $109 \mu \mathrm{l}$ of a $2375 \mathrm{wt} \%$ Nafion solution containing 15-20\% water, $300 \mu \mathrm{l}$ of ethanol 238 and $36 \mu l$ of de-ionized water was sonicated and mixed using a vortex 239 An aliquot of $7 \mu l$ was deposited on the glassy-carbon disk $\left(0.196 \mathrm{~cm}^{2}\right)$ 240 resulting in a catalyst loading of $800 \mu \mathrm{g} \cdot \mathrm{cm}^{-2}$. The working electrode 241 with the deposited catalyst layer was used in a three-electrode cell 242 setup connected to a potentiostat (Versastat 3, AMETEK) and rotator 243 (MSR, Pine Instruments). The counter electrode and reference elec244 trode were a graphite rod and a reversible hydrogen electrode (RHE), 245 respectively. The electrolyte was an $\mathrm{O}_{2}$-saturated aqueous solution of $2460.1 \mathrm{M} \mathrm{H}_{2} \mathrm{SO}_{4}$. The RDE polarization curves were recorded with a scan 247 rate of $10 \mathrm{mV} \cdot \mathrm{s}^{-1}$ at $1500 \mathrm{rpm}$ and corrected for the background cur248 rent measured in $\mathrm{N}_{2}$-saturated electrolyte. Additional measurements 249 were similarly performed with a rotating-ring disk electrode for de250 termination of the $\% \mathrm{H}_{2} \mathrm{O}_{2}$ released during ORR. The ring potential 251 was held at $1.2 \mathrm{~V}$ vs. RHE. Selected catalysts were investigated in 252 fuel cell. For the membrane electrode assembly (MEA), cathode inks 253 were prepared using the following formulation: $20 \mathrm{mg}$ of catalyst, $254652 \mu \mathrm{l}$ of a 5 wt\% Nafion solution containing 15-20\% water, 326 $255 \mu l$ of ethanol and $272 \mu l$ of de-ionized water. The inks were alterna256 tively sonicated and agitated with a vortex mixer every $15 \mathrm{~min}$, for a 257 total of $1 \mathrm{~h}$. Then, three aliquots of $405 \mu \mathrm{l}$ of the catalyst ink were 258 successively deposited on the microporous layer of an uncatalysed $2594.84 \mathrm{~cm}^{2}$ gas diffusion layer (Sigracet S10-BC) to reach a catalyst 260 loading of $4 \mathrm{mg} \mathrm{cm}^{-2}$. The cathode was then placed in a vacuum oven 261 at $90^{\circ} \mathrm{C}$ to dry for $1 \mathrm{~h}$. The anode used for all PEMFC tests performed 262 in this work was $0.5 \mathrm{mg}_{\mathrm{Pt}} \cdot \mathrm{cm}^{-2}$ on Sigracet $\mathrm{S} 10$-BC. MEAs were 263 prepared by hot-pressing $4.84 \mathrm{~cm}^{2}$ anode and cathode against either 264 side of a Nafion NRE-211 membrane at $125^{\circ} \mathrm{C}$ for 2 min. PEMFC 265 tests were performed with a single-cell fuel cell with serpentine flow 266 field (Fuel Cell Technologies Inc.) using an in-house fuel cell bench 267 and a Biologic Potentiostat with a 50 A load and EC-Lab software.
For the tests, the fuel cell temperature was $80^{\circ} \mathrm{C}$, the humidifiers were 268 set at $85^{\circ} \mathrm{C}$, and the inlet pressures were set to 1 bar gauge for both 269 anode and cathode sides. The flow rates for humidified $\mathrm{H}_{2}$ and $\mathrm{O}_{2} \quad 270$ were ca 50-70 sccm downstream of the fuel cell. Polarization curves 271 were recorded by scanning the cell voltage at $0.5 \mathrm{mV} \cdot \mathrm{s}^{-1}$.

\section{Results and Discussion}

273

Structural characterisation of pristine catalysts. - The X-ray 274 diffractograms for the pristine $\mathrm{Fe}-\mathrm{N}-\mathrm{C}, \mathrm{Co}-\mathrm{N}-\mathrm{C}$ and $\mathrm{Cr}-\mathrm{N}-\mathrm{C}$ cata- 275 lysts are shown in Figure 2. While the Fe-N-C and Co-N-C catalysts 276 only show two diffraction peaks that are assigned to the 002 and 101277 reflections of graphite, the $\mathrm{Cr}-\mathrm{N}-\mathrm{C}$ catalyst shows additional intense 278 peaks that are assigned to the $\mathrm{CrN}$ structure. In addition, secondary 279 peaks visible in the diffraction pattern of $\mathrm{Cr}-\mathrm{N}-\mathrm{C}$ are assigned to the 280 $\mathrm{Cr}_{2} \mathrm{~N}$ structure and to a chromium carbonitride structure. The major 281 presence of $\mathrm{CrN}$ over $\mathrm{Cr}_{2} \mathrm{~N}$ was expected after pyrolysis in the $\mathrm{N}-282$ rich atmosphere, $\mathrm{NH}_{3} .{ }^{42}$ The superimposition of the broad peaks at 283 $23-25^{\circ}$ that is assigned to graphite highlights a similar low degree of 284 graphitization. This is understandable since the metallic cobalt and 285 iron crystalline structures known to catalyze graphitisation are not 286 detected by XRD in the pristine Fe-N-C and Co-N-C catalysts while 287 chromium nitrides do not catalyze graphitization. ${ }^{29,43-44}$

The Fourier-transforms of the extended X-ray absorption fine 289 structure (EXAFS) spectra of the Fe-N-C and Co-N-C catalysts are 290 shown in Fig. 3a-3b (thick solid lines), while the corresponding 291 X-ray absorption near edge structure (XANES) spectra are shown 292 in Fig. 3d-3e. The radial distribution function of Fe-N-C shows a first 293 peak at 1.3-1.5 $\AA$ arising from Fe-N interactions and a second peak 294 at $2.2 \AA$ mostly assigned to backscattering from carbon atoms. Both 295 the EXAFS and XANES spectra for pristine Fe-N-C resemble those 296 of $\mathrm{Fe}(\mathrm{II})$ phthalocyanine $\left(\mathrm{Fe}^{\mathrm{II}} \mathrm{Pc}\right)$ (thin red line in Figs. 3a and 3d). 297 The main difference is the absence of a pre-edge peak at $7117 \mathrm{eV} \quad 298$ in the XANES spectrum of Fe-N-C, while it is present in the spec- 299 trum of $\mathrm{Fe}^{\mathrm{II}} \mathrm{Pc}$. The absence of the pre-edge feature in $\mathrm{Fe}-\mathrm{N}-\mathrm{C}$ can 300 be explained on the basis that the square-planar $\mathrm{D}_{4 \mathrm{~h}}$ local symmetry 301 is broken down in the Fe-N-C catalyst due to the additional coordi- 302 nation of dioxygen along the axial direction. ${ }^{45}$ The pre-edge feature 303 at $7117 \mathrm{eV}$ is indeed observed for square-planar $\mathrm{Fe}^{\mathrm{II}} \mathrm{N}_{4}$ compounds 304 but disappears for a square-pyramid coordination resulting from the 305 coordination by a fifth ligand. ${ }^{17,46} \mathrm{Such}$ is the case for Hemin, a chloro- 306 $\mathrm{Fe}(\mathrm{III})$-porphyrin compound (green line in Fig. 3d). Thus, the XANES 307 and EXAFS data for Fe-N-C show that i) the active-site structure in 308 $\mathrm{Fe}-\mathrm{N}-\mathrm{C}$ is similar to that in $\mathrm{Fe}^{\mathrm{II}} \mathrm{Pc}$ and ii) no or almost no $\mathrm{Fe}-\mathrm{Fe} \quad 309$ bonds exist in that catalyst. Similarly, the EXAFS data for Co-N-C 310 suggest that only few Co-Co bonds are present in the pristine cata- 311 lyst due to the small signal at 2.3-2.5 and 4-5 $\AA$ corresponding to 312

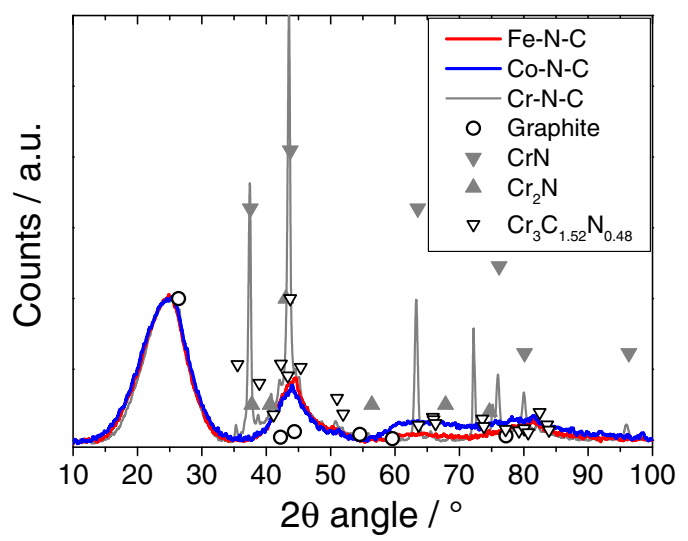

Figure 2. X-ray diffractograms of the pristine $\mathrm{Fe}-\mathrm{N}-\mathrm{C}, \mathrm{Co}-\mathrm{N}-\mathrm{C}$ and $\mathrm{Cr}-$ $\mathrm{N}-\mathrm{C}$ catalysts and reference X-ray diffraction lines for graphite (JCPDS file 75-1621), $\mathrm{CrN}$ (JCPDS file 11-0065), $\mathrm{Cr}_{2} \mathrm{~N}$ (JCPDS file 01-1232) and $\mathrm{Cr}_{3} \mathrm{C}_{1.52} \mathrm{~N}_{0.48}$ (JCPDS file 76-1037). 

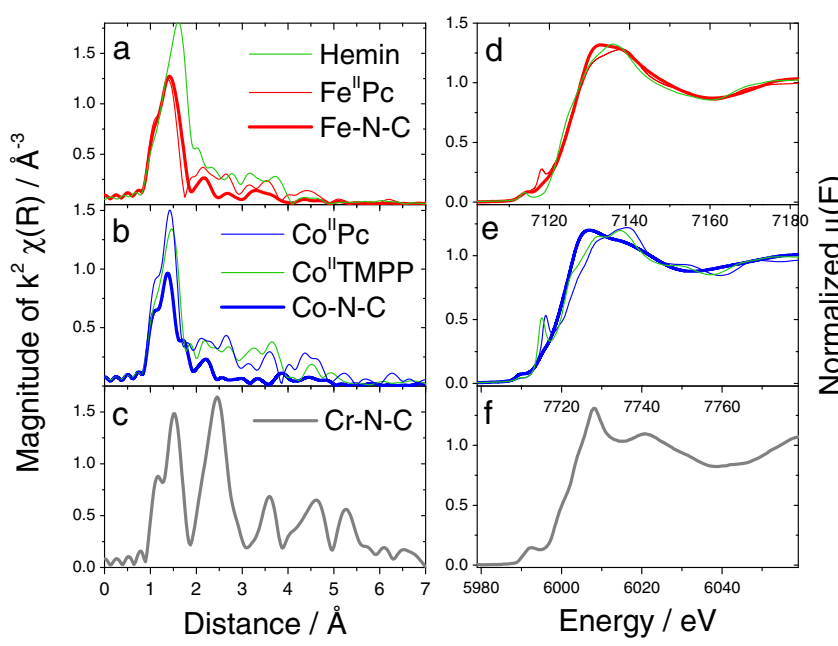

Figure 3. Left handside: Magnitude of the $\mathrm{k}^{2}$-weighed Fourier transform of the EXAFS signal for the pristine Fe-N-C, Co-N-C and Cr-N-C catalysts and for reference compounds. The radial distance is not corrected for phase shift. Right handside: the corresponding normalized XANES spectra, at energies between -10 and $+70 \mathrm{eV}$ around the corresponding Metal K-edge.

313 Co-Co bond distances in metallic cobalt (thick blue line in Fig. 3b). 314 On the basis of the relative intensity of the Fourier transform at $1.4 \AA$ 315 (Co-N interactions) for the present $\mathrm{Co}-\mathrm{N}-\mathrm{C}$ catalyst compared to that 316 of a Co-based catalyst free of metallic cobalt particles (lower cobalt 317 content), it was estimated that ca $79-83 \%$ of the cobalt atoms in the 318 present Co-N-C catalyst are involved in $\mathrm{CoN}_{\mathrm{x}} \mathrm{C}_{\mathrm{y}}$ moieties. Similar to 319 the case for iron, the pre-edge feature is observed for the square-planar $320 \mathrm{Co}^{\mathrm{II}} \mathrm{N}_{4}$ compounds $\mathrm{Co}^{\mathrm{II}} \mathrm{Pc}$ and $\mathrm{Co}(\mathrm{II})$-tetramethoxyphenylporphyrin

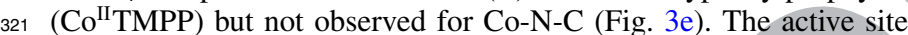
322 structure in $\mathrm{Co}-\mathrm{N}-\mathrm{C}$ is also different from that in $\mathrm{Co}^{\mathrm{II}} \mathrm{Pc}$ or $\mathrm{Co}^{\mathrm{II}} \mathrm{TMPP}$ 323 as revealed by the lower intensity of its Fourier transform at $1.4 \AA$, 324 corresponding to Co-N interactions (Fig. 3b). This suggests a lower 325 coordination of cobalt in $\mathrm{Co}-\mathrm{N}-\mathrm{C}$ than in $\mathrm{CoN}_{4}$ macrocycles. In con326 clusion, the restricted amount of metal-based crystalline structures in 327 the pristine $\mathrm{Co}$ - and $\mathrm{Fe}-\mathrm{N}-\mathrm{C}$ catalysts is important as it allows an eas328 ier tracking with X-ray absorption spectroscopy (XAS) of the fate of 329 the $\mathrm{CoN}_{\mathrm{x}} \mathrm{C}_{\mathrm{y}}$ and $\mathrm{FeN}_{\mathrm{x}} \mathrm{C}_{\mathrm{y}}$ moieties after $\mathrm{H}_{2} \mathrm{O}_{2}$ treatment. This aspect 330 had already proved important for post mortem Mössbauer analysis of $331 \mathrm{Fe}-\mathrm{N}-\mathrm{C}$ cathodes. ${ }^{21}$ Last, the Fourier transform function for $\mathrm{Cr}-\mathrm{N}-\mathrm{C}$ 332 shows a long-range ordering up to $6 \AA$, in agreement with the $\mathrm{CrN}$ 3 sз structure. The first peak at $1.5 \AA$ is assigned to $\mathrm{Cr}-\mathrm{N}$ interactions with $334 \mathrm{~N}$ atoms while the second and third peaks at 2.5 and $3.6 \AA$ are assigned 335 to $\mathrm{Cr}-\mathrm{Cr}$ interactions.

Electrochemical characterization of pristine and degraded 337 catalysts. - Figure 4 shows the polarization curves measured with $338 \mathrm{RDE}$ for the pristine $\mathrm{Fe}-\mathrm{N}-\mathrm{C}, \mathrm{Co}-\mathrm{N}-\mathrm{C}$ and $\mathrm{Cr}-\mathrm{N}-\mathrm{C}$ catalysts (thick 339 black curves) as well for the three series of catalysts obtained by 340 treating these catalysts with increasing amounts of $\mathrm{H}_{2} \mathrm{O}_{2}$. The po341 larization curves for the pristine $\mathrm{Fe}-$ and $\mathrm{Co}-\mathrm{N}-\mathrm{C}$ catalysts show a 342 gradual \transition from a kinetic control to a diffusion control ex343 tending over $150 \mathrm{mV}$. This is typical for catalytic films with poor 344 diffusion properties. These experimental curves are similar in shape 345 to those calculated for films including an $\mathrm{O}_{2}$ concentration gradient 346 at high current density. ${ }^{47}$ This does however not impede the reading 347 of the ORR activity at high potential where the current density is 348 low. For both Fe- and Co-N-C, the ORR activity at $0.8 \mathrm{~V}$ vs. RHE 349 gradually decreases with increasing amounts of $\mathrm{H}_{2} \mathrm{O}_{2}$ used during the 350 treatment, while the diffusion-limited current density is practically 351 unmodified. This suggests that the ORR mechanism was unchanged 352 while the number of $\mathrm{FeN}_{\mathrm{x}} \mathrm{C}_{\mathrm{y}}$ and $\mathrm{CoN}_{\mathrm{x}} \mathrm{C}_{\mathrm{y}}$ active sites on the surface 353 gradually decreased. The general trend of decreasing ORR activity 354 with increased amount of $\mathrm{H}_{2} \mathrm{O}_{2}$ used in the treatment is however more

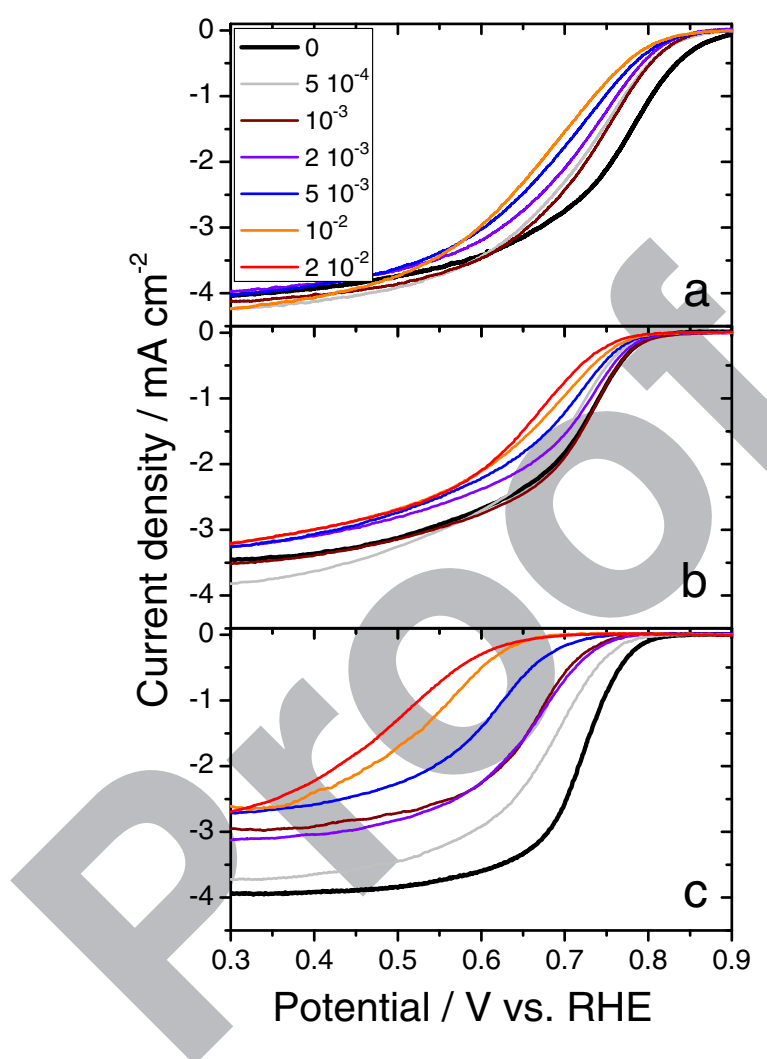

Figure 4. Polarization curves measured with RDE for a) Fe-N-C, b) Co-N$\mathrm{C}$ and c) $\mathrm{Cr}-\mathrm{N}-\mathrm{C}$ pristine catalysts and after ex situ treatment with various amounts of $\mathrm{H}_{2} \mathrm{O}_{2}$. The legend indicates the number of moles $\mathrm{H}_{2} \mathrm{O}_{2}$ per mg of catalyst used for treating Me-N-C catalysts.

complex at low peroxide amounts. For Fe-N-C, the ORR activities 355 after treatment with $5 \cdot 10^{-4}$ and $10^{-3} \mathrm{~mol} \mathrm{H}_{2} \mathrm{O}_{2}$ per mg of catalyst 356 are identical, suggesting that the degradation stalled. For Co-N-C, the 357 ORR activity first decreased after treatment with $5 \cdot 10^{-4} \mathrm{~mol}_{2} \mathrm{O}_{2} \quad 358$ per mg of catalyst, but rose back to the activity of pristine Co-N-C 359 after treatment with $10^{-3} \mathrm{~mol} \mathrm{H}_{2} \mathrm{O}_{2} \mathrm{mg}^{-1}$. For higher amounts of 360 $\mathrm{H}_{2} \mathrm{O}_{2}$, the ORR activity then decreased gradually for both $\mathrm{Fe}$ - and 361 Co-N-C. The $\mathrm{H}_{2} \mathrm{O}_{2}$ treatment seems to result in the superimposition 362 of a minor positive effect at low $\mathrm{H}_{2} \mathrm{O}_{2}$ amount and of a major negative 363 effect at high $\mathrm{H}_{2} \mathrm{O}_{2}$ amount. Following a restricted surface oxidation 364 with $\mathrm{H}_{2} \mathrm{O}_{2}$, the top surface of $\mathrm{Co}$ - or Fe-N-C might have been cleaned, 365 thereby exposing to the electrolyte some active sites that were pre- 366 viously buried under a thin carbon layer. Alternatively, the grafting 367 of oxygen groups on the surface might have positively affected the 368 ORR turnover of the active sites via electronic effects. ${ }^{48}$ Next, the ${ }_{369}$ pattern for Cr-N-C is different. The polarization curve of the pristine 370 catalyst is steeper in the kinetic region. The diffusion-limited current 371 density is also better defined. The decrease of the ORR activity after 372 $\mathrm{H}_{2} \mathrm{O}_{2}$ treatment is much larger than that observed for $\mathrm{Fe}-$ and $\mathrm{Co}-{ }_{373}$ $\mathrm{N}-\mathrm{C}$. This suggests that the nature of the active sites is completely 374 different, which is corroborated by XRD, XANES and EXAFS char- 375 acterisations (Figs. 2-3). As will be seen later, the chromium nitride ${ }_{376}$ structures resist the peroxide treatment, but they are ORR inactive. 377 The ORR activity of pristine Cr-N-C is assigned to highly basic N- 378 groups that are formed during pyrolysis in $\mathrm{NH}_{3}$. The assignment is 379 based on the poor ORR activity of a Cr-based sample pyrolyzed in $\mathrm{Ar} 380$ and also on the high activity of a metal-free $\mathrm{N}-\mathrm{C}$ sample pyrolyzed in 381 $\mathrm{NH}_{3}$ (not shown). Regarding the diffusion-limited current density, the 382 pattern is also very different from that observed for Fe- and Co-N-C. 383 The ORR mechanism seems to gradually shift from a four-electron 384 to a two-electron reduction mechanism (Fig. 4c). This is understand- 385 able if the top-surface $\mathrm{N}$-groups present in pristine $\mathrm{Cr}-\mathrm{N}-\mathrm{C}$ were re- 386 moved from the surface during the treatment with $\mathrm{H}_{2} \mathrm{O}_{2}$, or chemically 387 


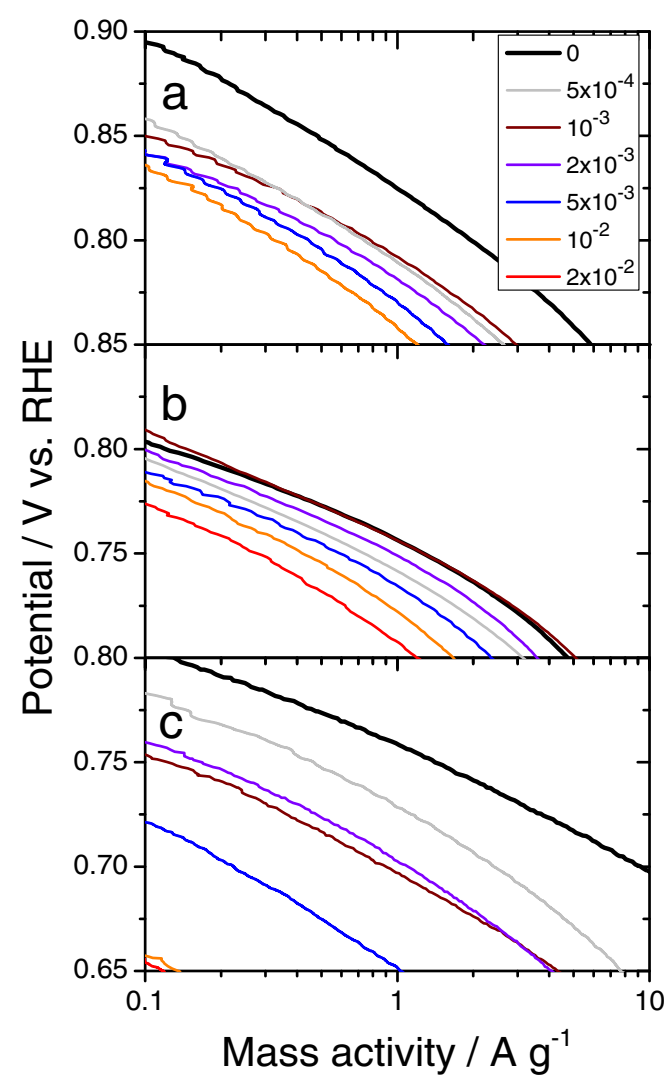

Figure 5. Tafel plots derived from RDE polarization curves for a) Fe-N-C, b) $\mathrm{Co}-\mathrm{N}-\mathrm{C}$ and c) $\mathrm{Cr}-\mathrm{N}-\mathrm{C}$ catalysts initially and after ex situ treatment with various amounts of $\mathrm{H}_{2} \mathrm{O}_{2}$. The legend indicates the number of moles $\mathrm{H}_{2} \mathrm{O}_{2}$ per $\mathrm{mg}$ of catalyst used to treat Me-N-C catalysts.

388 modified. The low ORR activity remaining after extensive degrada389 tion with $\mathrm{H}_{2} \mathrm{O}_{2}$ possibly comes from less active $\mathrm{N}$-groups or from 390 oxygen groups that formed during the peroxide treatment. In order to 391 quantify the ORR activity, the polarization curves were corrected for 392 diffusion limitation with the Koutecky-Levich equation and normal393 ized per mass of catalyst. Figure 5 shows the Tafel plots corresponding 394 to Figure 4. Within a given catalyst series, the Tafel slopes remained 395 constant with $\mathrm{H}_{2} \mathrm{O}_{2}$ treatment, except for pristine $\mathrm{Fe}-\mathrm{N}-\mathrm{C}$ for which 396 the Tafel slope is slightly higher than that for treated catalysts (77 397 vs. $62-65 \mathrm{mV} \mathrm{dec}^{-1}$ ). The ORR activity after treatment with $10^{-2}$ $398 \mathrm{~mol} \mathrm{H}_{2} \mathrm{O}_{2} \mathrm{mg}^{-1}$ was divided by 6.6 for $\mathrm{Fe}-\mathrm{N}-\mathrm{C}, 2.9$ for $\mathrm{Co}-\mathrm{N}-\mathrm{C}$ and 3991400 for $\mathrm{Cr}-\mathrm{N}-\mathrm{C}$ (Fig. 5). The activity was read at $0.8 \mathrm{~V}$ vs. RHE 400 for $\mathrm{Fe}-$ and $\mathrm{Co}-\mathrm{N}-\mathrm{C}$, and at $0.75 \mathrm{~V}$ vs. RHE for $\mathrm{Cr}-\mathrm{N}-\mathrm{C}$. Thus, the 401 ORR activity decay following $\mathrm{H}_{2} \mathrm{O}_{2}$ treatment strongly depends on 402 the nature of the metal in Me-N-C catalysts. This in turn strongly sug403 gests that the oxidizing species degrading the catalysts is not $\mathrm{H}_{2} \mathrm{O}_{2}$ 404 but rather the ROS generated via a Fenton reaction between transition 405 metal atoms and $\mathrm{H}_{2} \mathrm{O}_{2}$. Direct evidence for the formation of ROS is 406 reported in Collection yield and radical oxygen species after ex situ $407 \mathrm{H}_{2} \mathrm{O}_{2}$ treatment section.

408 The ORR mechanism on pristine catalysts was then investigated 409 with a rotating ring disk electrode (RRDE). Measured at a loading 410 of $0.8 \mathrm{mg} \mathrm{cm}^{-2}$, the $\% \mathrm{H}_{2} \mathrm{O}_{2}$ detected at the ring is shown in Fig. $6 \mathrm{a}$ 411 and the polarization curves measured at the disk are shown in Fig. $6 \mathrm{~b}$. 412 The $\% \mathrm{H}_{2} \mathrm{O}_{2}$ is far lower for ORR when catalyzed by $\mathrm{Fe}-\mathrm{N}-\mathrm{C}$ than 413 catalyzed by Co-N-C and Cr-N-C. The curves of $\% \mathrm{H}_{2} \mathrm{O}_{2}$ vs. potential 414 for $\mathrm{Fe}-\mathrm{N}-\mathrm{C}$ and $\mathrm{Co}-\mathrm{N}-\mathrm{C}$ have a similar shape, but $\mathrm{Co}-\mathrm{N}-\mathrm{C}$ produces ca 41520 times more $\mathrm{H}_{2} \mathrm{O}_{2}$ at any given potential. For $\mathrm{Cr}-\mathrm{N}-\mathrm{C}$, the $\% \mathrm{H}_{2} \mathrm{O}_{2}$ is 416 quite high and almost independent of potential. In order to investigate 417 whether the low $\% \mathrm{H}_{2} \mathrm{O}_{2}$ measured on $\mathrm{Fe}-\mathrm{N}-\mathrm{C}$ indicates a true four 418 electron reduction mechanism, a $2+2$ electron mechanism or a

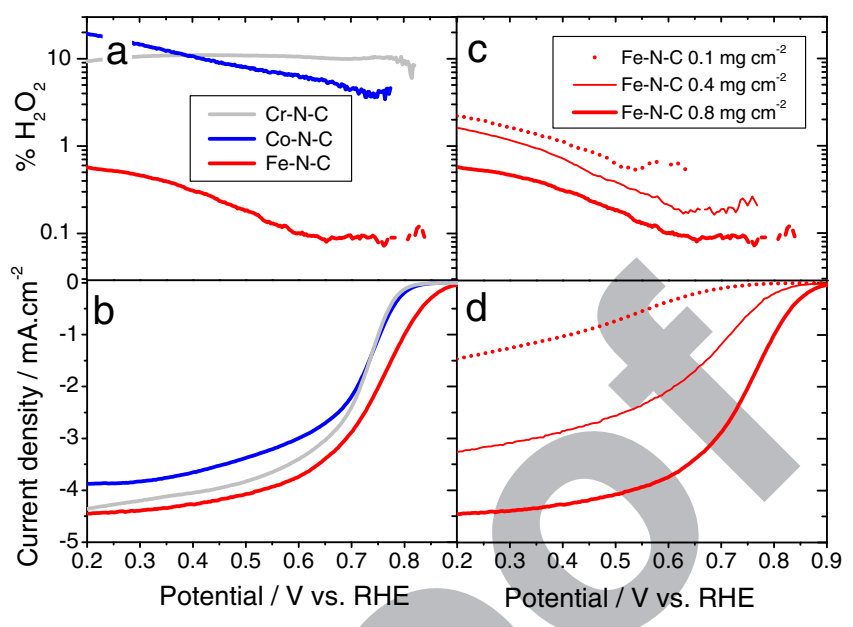

Figure 6. Rotating ring disk electrode measurements for Fe-N-C, Co-N-C and $\mathrm{Cr}-\mathrm{N}-\mathrm{C}$ (left handside) at a fixed loading of $0.8 \mathrm{mg} \mathrm{cm}^{-2}$ and rotating ring disk electrode measurements for $\mathrm{Fe}-\mathrm{N}-\mathrm{C}$ at different loading (right handside). In $\mathrm{c}$ and $\mathrm{d}$, the loading at the disk was $0.8 \mathrm{mg} \mathrm{cm}^{-2}$ (thick solid line), $0.4 \mathrm{mg} \mathrm{cm}^{-2}$ (thin solid line) or $0.1 \mathrm{mg} \mathrm{cm}^{-2}$ (dashed line).

two-electron mechanism followed by chemical disproportionation, 419 lower Fe-N-C loadings were investigated (Fig. 6c-6d). ${ }^{49}$ At lower 420 loadings, the diffusion-limited current density was drastically reduced 421 (Fig. 6d), due to incomplete coverage of the disk, or due to a low 422 density of active sites per geometric area of the disk. This drastic de- 423 crease does not reflect the small change in $\% \mathrm{H}_{2} \mathrm{O}_{2}$ that is detected at 424 the ring. The $\% \mathrm{H}_{2} \mathrm{O}_{2}$ increased with decreased loading, but remained 425 in the range $3.3-4.5 \%$ at potentials of $0.2-0.6 \mathrm{~V}$ vs. RHE even at ${ }_{426}$ $0.1 \mathrm{mg}_{\mathrm{Fe}-\mathrm{N}-\mathrm{C}} \mathrm{cm}^{-2}$ (dashed curve in Fig. 6d). This shows that ORR ${ }_{427}$ on $\mathrm{Fe}-\mathrm{N}-\mathrm{C}$ proceeds mostly according to a direct four electron 428 mechanism. The minute amount of $\mathrm{H}_{2} \mathrm{O}_{2}$ formed on the catalyst 429 surface may however have formed ROS through a chemical reaction 430 on $\mathrm{FeN}_{\mathrm{x}} \mathrm{C}_{\mathrm{y}}$ moieties.

While the RDE and RRDE techniques are useful for investigating 432 the ORR activity and ORR mechanism, they do not allow predicting 433 the behavior of Me-N-C cathodes at high current density in PEMFC. ${ }_{434}$ We selected the pristine catalysts and catalysts treated with $2 \cdot 10^{-3} \quad{ }_{435}$ and $10^{-2} \mathrm{~mol} \mathrm{H}_{2} \mathrm{O}_{2} \mathrm{mg}^{-1}$ for beginning-of-life (BoL) PEMFC tests. ${ }_{436}$ Figure 7 shows PEMFC polarization curves recorded with $4 \mathrm{mg} \mathrm{cm}^{-2} \quad{ }_{437}$ of Me-N-C catalyst at the cathode. Analyzing the extent of degrada- 438 tion after ex situ $\mathrm{H}_{2} \mathrm{O}_{2}$ treatment should a priori be carried out by 439 comparing the $\mathrm{BoL}$ polarisation curve of $\mathrm{H}_{2} \mathrm{O}_{2}$-treated catalysts to 440 the BoL polarization curves of the corresponding pristine catalysts. 441 However, for the pristine $\mathrm{Fe}-$ and $\mathrm{Co}-\mathrm{N}-\mathrm{C}$ catalysts, this simple ap- 442 proach is impeded by the fact that the BoL polarization curve does 443 not correspond to the best performance of the pristine catalysts. For 444 pristine $\mathrm{Fe}-\mathrm{N}-\mathrm{C}$, the polarization curve continuously improves during 445 the first $6 \mathrm{~h}$ of operation, and the same occurs for pristine Co-N-C 446 during the first $15 \mathrm{~h}$ of operation. The improvement is most visible 447 in the high current density region, while the ORR activity at high 448 potential slightly decreases during this break-in period (Fig. 7a-7b). 449 The break-in phenomenon is assigned to changes in the hydrophilic 450 properties of the catalytic surface that had never been in contact with 451 water previously. This break-in period is neither observed for pristine 452 $\mathrm{Cr}-\mathrm{N}-\mathrm{C}$ nor for any $\mathrm{H}_{2} \mathrm{O}_{2}$-treated catalyst. When the high current den- 453 sity region is considered, the reference curves for the pristine $\mathrm{Fe}-\mathrm{N}-\mathrm{C} \quad 454$ and $\mathrm{Co}-\mathrm{N}-\mathrm{C}$ catalysts will therefore be the polarisation curves after 455 break-in (dotted black lines in Fig. 7a-7b). When the ORR activity 456 at $0.8 \mathrm{~V}$ is considered, the reference curves for the pristine Fe-N- 457 $\mathrm{C}$ and $\mathrm{Co}-\mathrm{N}-\mathrm{C}$ catalysts will be the BoL polarization curves (solid 458 black lines in Fig. 7a-7b). The current densities measured at 0.8 and 459 $0.5 \mathrm{~V}$ in fuel cell as extracted from Fig. 7 for pristine and $\mathrm{H}_{2} \mathrm{O}_{2}$-treated 460 catalysts are summarized in Figure 8. 


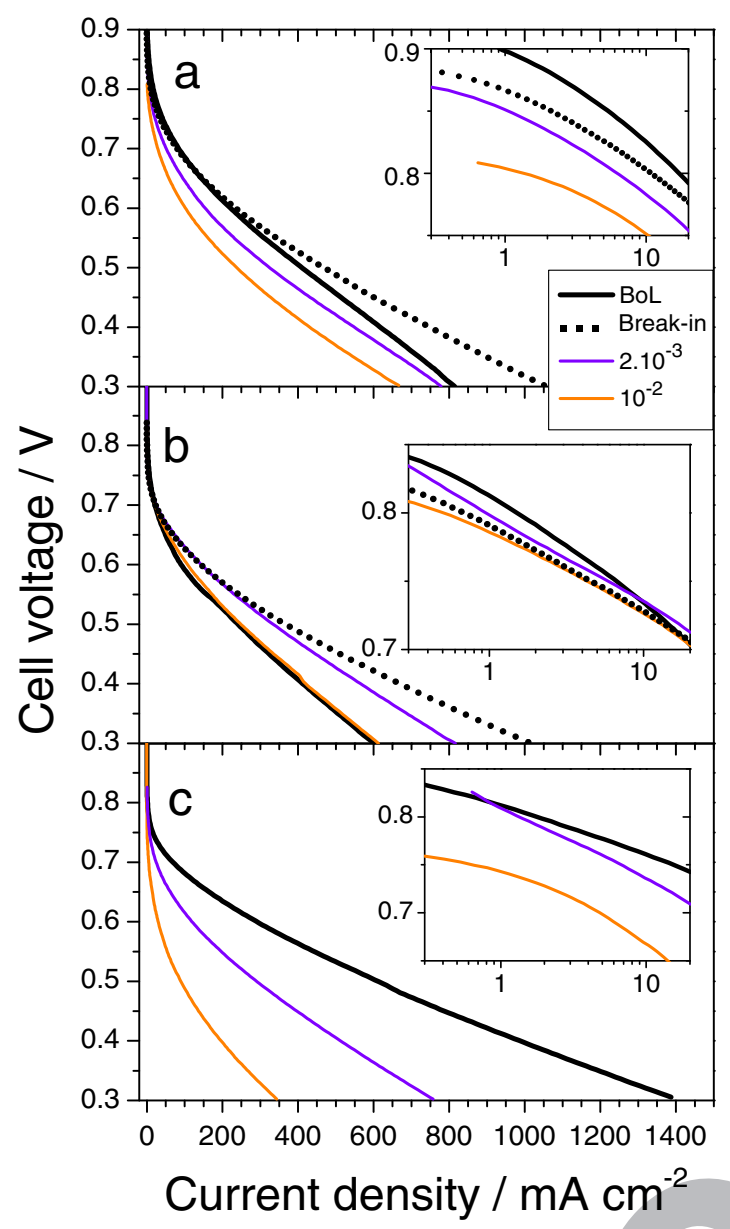

Figure 7. Effect of ex situ $\mathrm{H}_{2} \mathrm{O}_{2}$ treatment on the fuel cell polarization curves of MEAs with cathodes comprising a) Fe-N-C, b) Co-N-C and c) $\mathrm{Cr}-\mathrm{N}-\mathrm{C}$ catalysts. The insets show the high-potential region of the polarization curves in semi-logarithmic plot. The break-in involved potentiostatic control at $0.5 \mathrm{~V}$ for $6 \mathrm{~h}$ (pristine $\mathrm{Fe}-\mathrm{N}-\mathrm{C}$ ) or $15 \mathrm{~h}$ (pristine $\mathrm{Co}-\mathrm{N}-\mathrm{C}$ ). 465 a treatment with $10^{-2} \mathrm{~mol} \mathrm{H}_{2} \mathrm{O}_{2} \mathrm{mg}^{-1}$, the ORR activity measured in $466 \mathrm{PEMFC}$ at $0.8 \mathrm{~V}$ was divided by ca 45 for $\mathrm{Cr}-\mathrm{N}-\mathrm{C}$, by 9 for $\mathrm{Fe}-\mathrm{N}-\mathrm{C}$ 467 and by 3 for Co-N-C (Fig. 8b). These numbers are comparable to those 468 measured with RDE, except for $\mathrm{Cr}-\mathrm{N}-\mathrm{C}$ for which the decay in fuel 469 cell is much smaller than the one measured in RDE (Fig. 5c and 7c). At $4700.5 \mathrm{~V}$, the decrease in current density from the BoL polarization curve 471 (Cr-N-C), or from the polarisation curve after break-in (for Co- and $472 \mathrm{Fe}-\mathrm{N}-\mathrm{C}$ ) to the BoL polarisation curve measured for catalysts treated 473 with $10^{-2} \mathrm{~mol} \mathrm{H}_{2} \mathrm{O}_{2} \mathrm{mg}^{-1}$ is highest for $\mathrm{Cr}-\mathrm{N}-\mathrm{C}$ (decrease from 606 474 to $85 \mathrm{~mA} \mathrm{~cm}^{-2}$ ), followed by Fe-N-C (470 to $\left.238 \mathrm{~mA} \mathrm{~cm}^{-2}\right)$ and 475 smallest for Co-N-C (366 to $240 \mathrm{~mA} \mathrm{~cm}^{-2}$ ). Noteworthy, the ORR 476 activity at $0.8 \mathrm{~V}$ is almost identical for the pristine Co-N-C catalyst 477 after break-in and for the $\mathrm{Co}-\mathrm{N}-\mathrm{C}$ catalyst after treatment with $10^{-2}$ $478 \mathrm{~mol} \mathrm{H}_{2} \mathrm{O}_{2} \mathrm{mg}^{-1}$ (Fig. 8b). In spite of this, a large difference is observed 479 in the current density at $0.5 \mathrm{~V}$ (Fig. 8a). Thus, for Co-N-C, the loss of 480 performance at high current density induced by the peroxide treatment 481 is mostly due to decreased transport properties of the cathode layer. 482 The story is different for Fe-N-C and Cr-N-C. The Fe-N-C catalyst 483 shows a stronger decay of its ORR activity after peroxide treatment 484 (Fig. 8b) but the transport properties of the cathode layer are also 485 negatively impacted by the ex situ peroxide treatment of the catalyst, 486 as can be deduced from the steeper slope of the polarization curve 487 at high current density (Fig. 7a). The $\mathrm{Cr}-\mathrm{N}-\mathrm{C}$ based cathode shows a

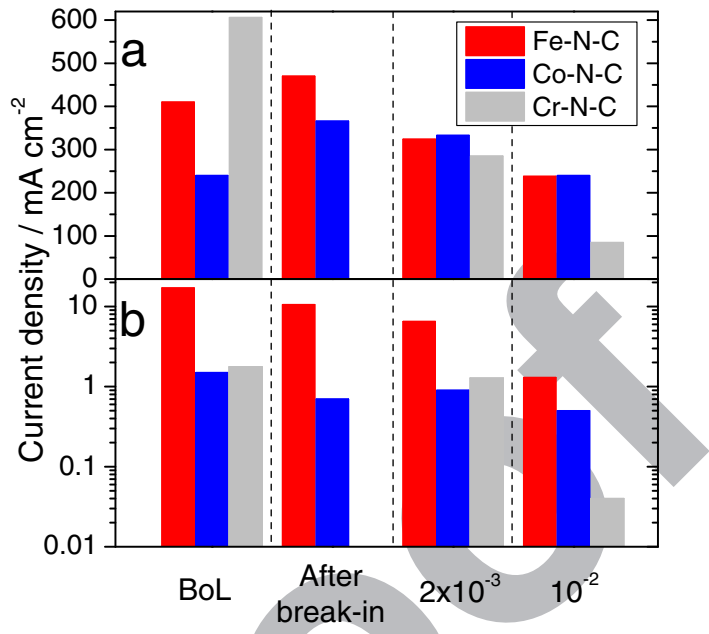

Figure 8. Current density measured in PEMFC at $0.5 \mathrm{~V}$ (a) and $0.8 \mathrm{~V}$ (b) for the pristine catalysts at $\mathrm{BoL}$ or after break-in, and for the catalysts after treatment with $2 \cdot 10^{-3}$ or $10^{-2} \mathrm{~mol} \mathrm{H}_{2} \mathrm{O}_{2} \mathrm{mg}^{-1}$. The break-in involved potentiostatic control at $0.5 \mathrm{~V}$ for $6 \mathrm{~h}$ (pristine $\mathrm{Fe}-\mathrm{N}-\mathrm{C}$ ) or $15 \mathrm{~h}$ (pristine Co-N-C). No break-in was applied to Cr-N-C. The activity of Cr-N-C at $0.8 \mathrm{~V}$ after $10^{-2}$ mol $\mathrm{H}_{2} \mathrm{O}_{2} \mathrm{mg}^{-1}$ needed an extrapolation.

dramatic decrease of both its ORR activity and transport properties 488 due to the $\mathrm{H}_{2} \mathrm{O}_{2}$ ex situ treatment of the $\mathrm{Cr}-\mathrm{N}-\mathrm{C}$ catalyst (Fig. 8, gray 489 columns).

Collection yield and radical oxygen species after ex situ $\mathrm{H}_{2} \mathrm{O}_{2} \quad 491$ treatment.- The weight percentage of catalyst powder collected af- 492 ter each $\mathrm{H}_{2} \mathrm{O}_{2}$ treatment is reported in Fig. 9a. After a treatment with 493 $5 \cdot 10^{-4}$ to $5 \cdot 10^{-3} \mathrm{~mol} \mathrm{H}_{2} \mathrm{O}_{2} \mathrm{mg}^{-1}$, the collection yields are $87-90 \% \quad 494$ for $\mathrm{Fe}-\mathrm{N}-\mathrm{C}$ (red bars) and 77-85\% for $\mathrm{Cr}-\mathrm{N}-\mathrm{C}$ (gray bars). Collection 495 yields lower than $100 \%$ can be due to i) handling loss, ii) chemical 496 loss due to the oxidative attack by peroxide and ii) filtration loss. The ${ }_{497}$ latter occurs if, at the end of the treatment, some catalytic particles 498 are smaller than the pore size of the filter used to separate the treated 499

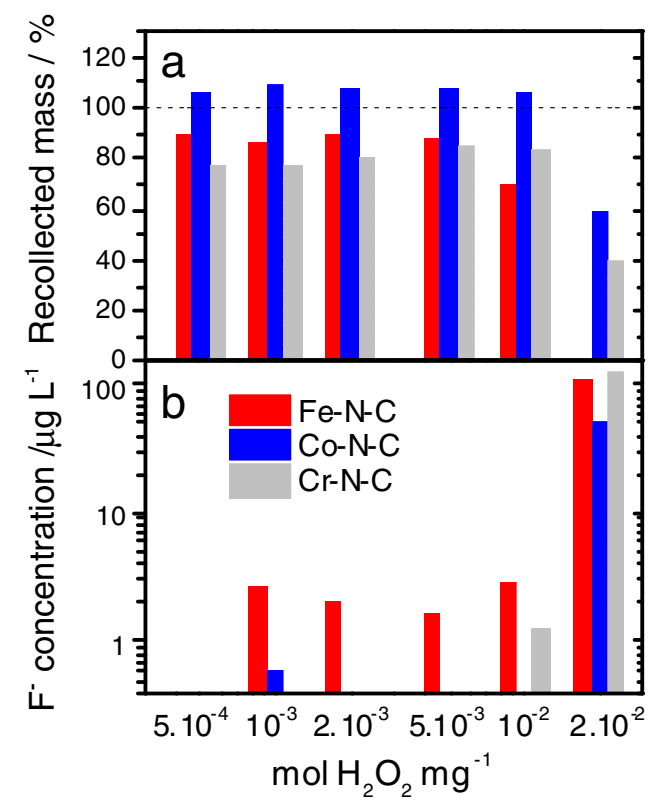

Figure 9. Extent of the $\mathrm{H}_{2} \mathrm{O}_{2}$ ex situ degradation assessed a) with the relative mass of catalyst recollected after each $\mathrm{H}_{2} \mathrm{O}_{2}$ treatment + filtration + drying, or b) with the concentration in the filtrate of fluoride ions released by a Nafion membrane. 
500 catalyst from the solution. The non-collected mass of catalyst for the 501 treated $\mathrm{Fe}-\mathrm{N}-\mathrm{C}$ and $\mathrm{Cr}-\mathrm{N}-\mathrm{C}$ samples is mostly assigned to chemical 502 and filtration losses. The loss due to material's handling is believed to 503 be negligible since for $\mathrm{Co}-\mathrm{N}-\mathrm{C}$ samples handled similarly, a weight 504 gain was observed after treatment up to $10^{-2} \mathrm{~mol} \mathrm{H}_{2} \mathrm{O}_{2} \mathrm{mg}^{-1}$ (blue 505 bars in Fig. 9a). This weight gain is assigned to the grafting of oxygen 506 functionalities on the surface of $\mathrm{Co}-\mathrm{N}-\mathrm{C}$, without any loss of carbon 507 atoms from Co-N-C. This explanation is supported by XPS elemen508 tal analysis (III.6). The lower collection yields for Cr-N-C samples 509 than for $\mathrm{Fe}-\mathrm{N}-\mathrm{C}$ samples is assigned to the higher porosity and higher 510 specific area of the pristine $\mathrm{Cr}-\mathrm{N}-\mathrm{C}$ catalyst due to the ammonia gas 511 used during pyrolysis. A significant decrease of the collection yield 512 is observed at and above $10^{-2} \mathrm{~mol} \mathrm{H}_{2} \mathrm{O}_{2} \mathrm{mg}^{-1}$. After treatment with $5132 \cdot 10^{-2} \mathrm{~mol} \mathrm{H}_{2} \mathrm{O}_{2} \mathrm{mg}^{-1}$, only 60 and $40 \%$ of the initial Co-N-C 514 and $\mathrm{Cr}-\mathrm{N}-\mathrm{C}$ mass was collected whereas no Fe-N-C catalyst could 515 be collected on the filter. A large fraction of the missing mass of 516 catalyst is suspected to have passed through the $220 \mathrm{~nm}$ sized pores 517 of the filter as a consequence of finer powders following the $\mathrm{H}_{2} \mathrm{O}_{2}$ 518 treatment. This hypothesis is supported by the greyish color of the 519 filtrates after treatment with large amounts of peroxide. The lower 520 granulometry of the powders after extended treatment with perox521 ide may explain the poorer transport properties of fuel cell cathodes 522 (Fig. 7). The cathode macroporosity may have decreased due to a 523 lower 3D branching character and lower inter-particle connections for $524 \mathrm{H}_{2} \mathrm{O}_{2}$-treated catalysts. In conclusion, after treatment with $10^{-2} \mathrm{~mol}$ $525 \mathrm{H}_{2} \mathrm{O}_{2} \mathrm{mg}^{-1}$, the extent of catalyst modification clearly depends on the 526 nature of the transition metal in Me-N-C catalysts, in the order $\mathrm{Fe}>\mathrm{Cr}$ $527>$ Co. This, in turn, might be related to the production of ROS ensuing 528 from the reaction between $\mathrm{H}_{2} \mathrm{O}_{2}$ and metal species. The production 529 of ROS during the peroxide treatment was quantified with the con530 centration of fluoride ions measured in the filtrate at the end of each 531 treatment. These fluoride ions originate from the simultaneous attack 532 by ROS of the Nafion membrane immersed in the solution during the 533 entire process. While the fluoride concentration remained low after 534 treatment up to $5.10^{-3} \mathrm{~mol} \mathrm{H}_{2} \mathrm{O}_{2} \mathrm{mg}^{-1}$, it dramatically increased by 535 ca two orders of magnitude for all three catalysts after a treatment with $5362 \cdot 10^{-2} \mathrm{~mol} \mathrm{H}_{2} \mathrm{O}_{2} \mathrm{mg}^{-1}$ (Fig. 9b). A correlation is observed between 537 a high collection yield and a low concentration of fluoride, suggesting 538 that $\mathrm{Co}-\mathrm{N}-\mathrm{C}$ produces less ROS than $\mathrm{Fe}-\mathrm{N}-\mathrm{C}$ when it is contacted 539 by $\mathrm{H}_{2} \mathrm{O}_{2}$. This explains the restricted decrease of the electrochemical 540 performance of $\mathrm{Co}-\mathrm{N}-\mathrm{C}$ after $\mathrm{H}_{2} \mathrm{O}_{2}$ treatment.

$541 X$-ray absorption spectroscopy on pristine and degraded 542 catalysts. - The XANES spectra for the three series of $\mathrm{H}_{2} \mathrm{O}_{2}$ treated 543 catalysts are shown in Fig. 10. For $\mathrm{Fe}-\mathrm{N}-\mathrm{C}$, there is practically no 544 change of the XANES spectra from the pristine $\mathrm{Fe}-\mathrm{N}-\mathrm{C}$ catalyst up to 545 the highly degraded catalyst after treatment with $10^{-2} \mathrm{~mol} \mathrm{H}_{2} \mathrm{O}_{2} \mathrm{mg}^{-1}$ 546 (Fig. 10a). Also the Fourier-transforms of the EXAFS spectra of the 547 Fe-N-C samples did not reveal any changes and were identical to that 548 of pristine Fe-N-C shown in Fig. 3a. The XANES and EXAFS spec549 tra of the Fe-based series therefore demonstrate that the coordination 550 chemistry of the $\mathrm{Fe}$ atoms that remained in the samples after $\mathrm{H}_{2} \mathrm{O}_{2}$ 551 treatment is identical to the one before treatment. It is paramount to 552 realize that this observation does not preclude the possibility that the $553 \mathrm{FeN}_{\mathrm{x}} \mathrm{C}_{\mathrm{y}}$ moieties located on the top-surface in pristine $\mathrm{Fe}-\mathrm{N}-\mathrm{C}$ were 554 partially or fully removed during $\mathrm{H}_{2} \mathrm{O}_{2}$ treatment. If similar $\mathrm{FeN}_{\mathrm{x}} \mathrm{C}_{\mathrm{y}}$ 555 moieties are present both on the top surface and in the bulk of pristine $556 \mathrm{Fe}-\mathrm{N}-\mathrm{C}$, the normalized XANES and EXAFS spectra will remain un557 changed even after the complete removal of top surface sites due to 558 the bulk-averaging nature of XANES and EXAFS. Hence, identical 559 spectra before and after $\mathrm{H}_{2} \mathrm{O}_{2}$ treatment is not paradoxical with the 560 decreased ORR activity before and after $\mathrm{H}_{2} \mathrm{O}_{2}$ treatment. It strongly 561 suggests, however, that only a fraction of the $\mathrm{FeN}_{\mathrm{x}} \mathrm{C}_{\mathrm{y}}$ moieties existing 562 in pristine $\mathrm{Fe}-\mathrm{N}-\mathrm{C}$ were located on the top surface. Only the latter may 563 contribute to the ORR activity. For the series of $\mathrm{H}_{2} \mathrm{O}_{2}$-treated samples 564 derived from pristine $\mathrm{Co}-\mathrm{N}-\mathrm{C}$, the XANES spectra changed notice565 ably with $\mathrm{H}_{2} \mathrm{O}_{2}$ treatment (Fig. 10b). The inset in Fig. 10b shows 566 the initial increase of the white line intensity at ca $7726 \mathrm{eV}$ after 567 treatment with $5 \cdot 10^{-4}$ and $10^{-3} \mathrm{~mol} \mathrm{H}_{2} \mathrm{O}_{2} \mathrm{mg}^{-1}$, followed by a con-

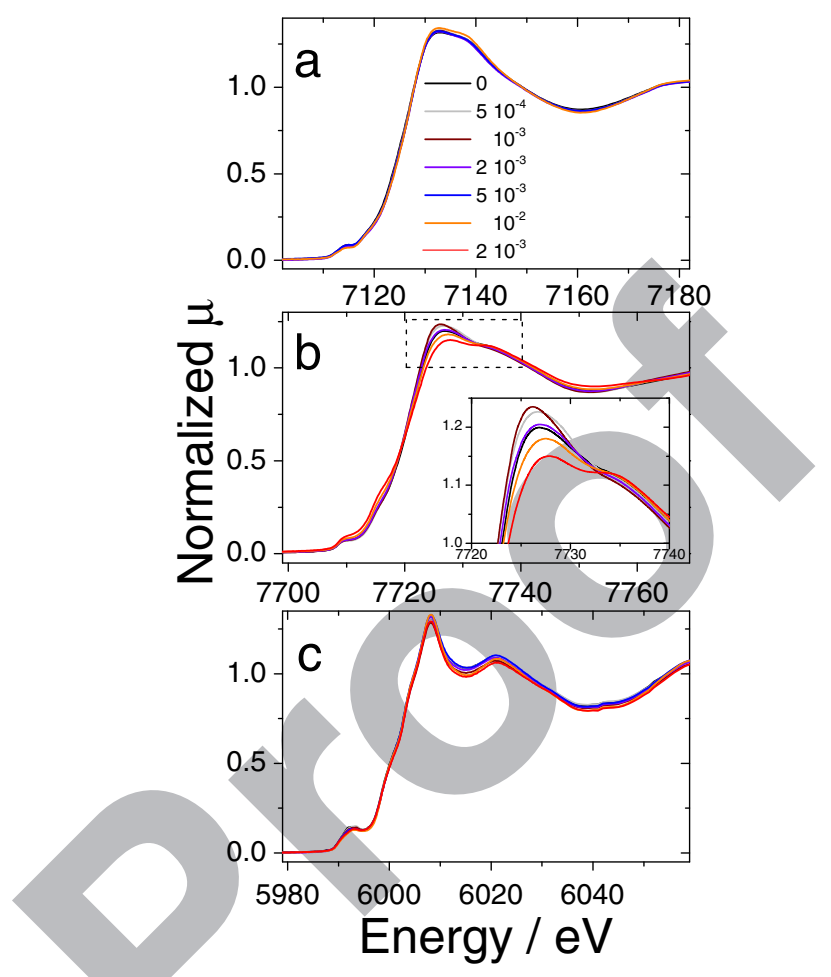

Figure 10. Normalized XANES spectra for pristine and $\mathrm{H}_{2} \mathrm{O}_{2}$ treated catalysts. a) Fe-N-C, b) Co-N-C, c) Cr-N-C. The spectra are shown in the energy range -10 to $+70 \mathrm{eV}$ around the corresponding Metal K-edge.

tinuous decrease from $10^{-3}$ to $2 \cdot 10^{-2} \mathrm{~mol} \mathrm{H}_{2} \mathrm{O}_{2} \mathrm{mg}^{-1}$. Noteworthy, 568 after treatment with $10^{-3} \mathrm{~mol} \mathrm{H}_{2} \mathrm{O}_{2} \mathrm{mg}^{-1}$, the ORR activity measured 569 in RDE increased back to the ORR activity of pristine Co-N-C, and 570 these two observations might be interrelated. The two XANES spectra 571 corresponding to treatments with $10^{-2}$ and $2 \cdot 10^{-2} \mathrm{~mol} \mathrm{H}_{2} \mathrm{O}_{2} \mathrm{mg}^{-1}$ are 572 significantly different at $7726 \mathrm{eV}$ and are also negatively shifted by 573 $1.5-2.5 \mathrm{eV}$ at the beginning of the absorption edge $(7715 \mathrm{eV})$. This in- 574 dicates a decreased average oxidation state of cobalt. This observation 575 is further supported by the Fourier-transforms of the EXAFS signal, 576 showing an increased peak at ca 2.2, 3.8 and $4.5 \AA$ (Fig. 11). These 577 distances (not corrected for phase shift) correspond to back-scattering 578 from cobalt atoms in metallic cobalt. Extensive treatment with $\mathrm{H}_{2} \mathrm{O}_{2} \quad 579$ probably resulted in the etching of a significant fraction of the $\mathrm{CoN}_{x} \mathrm{C}_{y} \quad 580$ moieties present in pristine $\mathrm{Co}-\mathrm{N}-\mathrm{C}$, thereby increasing the fraction of 581

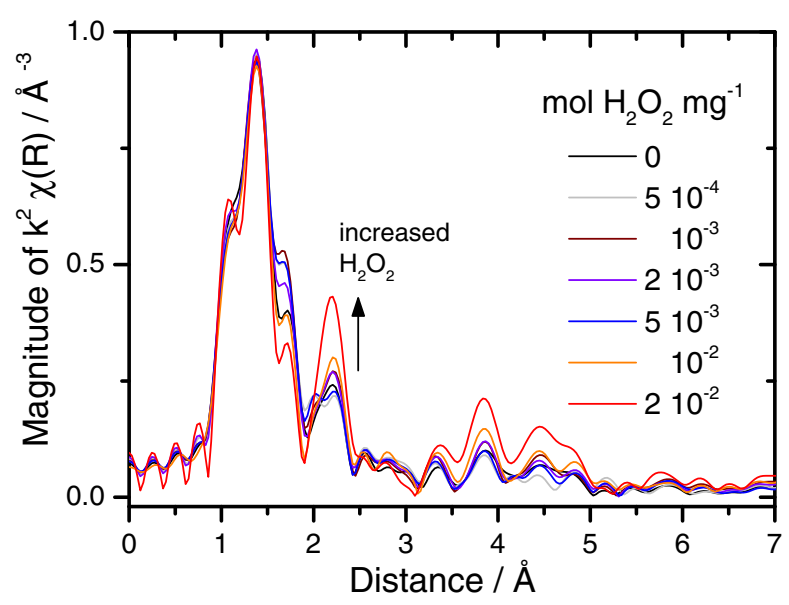

Figure 11. Magnitude of the $\mathrm{k}^{2}$-weighed Fourier transform of the EXAFS signal for pristine $\mathrm{Co}-\mathrm{N}-\mathrm{C}$ and for $\mathrm{H}_{2} \mathrm{O}_{2}$ treated $\mathrm{Co}-\mathrm{N}-\mathrm{C}$. The radial distance is not corrected for phase shift. 


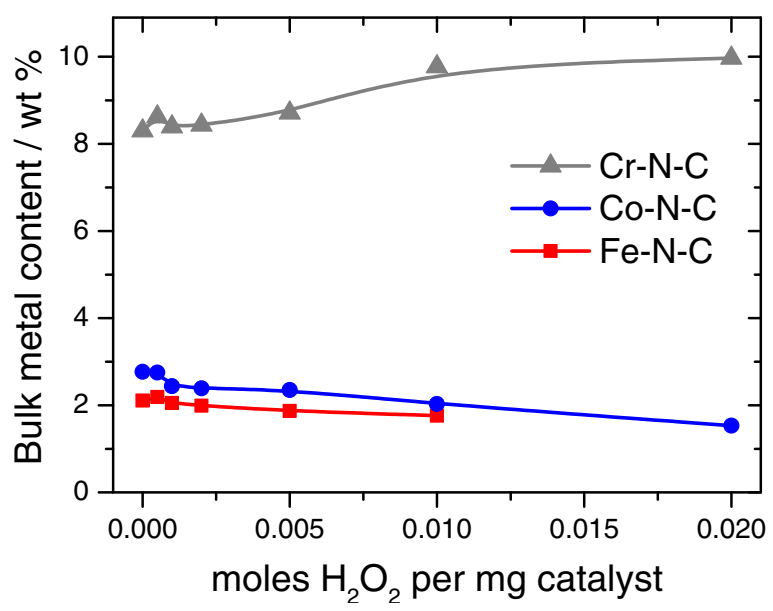

Figure 12. Bulk metal content as a function of the ratio of $m o l \mathrm{H}_{2} \mathrm{O}_{2}$ per mass catalyst used for ex situ degradation.

582 metallic cobalt in the treated $\mathrm{Co}-\mathrm{N}-\mathrm{C}$ samples. Pristine $\mathrm{Co}-\mathrm{N}-\mathrm{C}$ seems 583 to contain a small fraction of metallic cobalt (Fig. 11), although it was 584 not detected by XRD (Fig. 2). The better resistance of metallic cobalt 585 particles to the peroxide treatment is normal since such particles are 586 usually surrounded by a continuous layer of graphitic carbon after 587 pyrolysis. Next, the XANES spectra for the pristine and treated $\mathrm{Cr}-\mathrm{N}$ ${ }_{588} \mathrm{C}$ catalysts show little change with $\mathrm{H}_{2} \mathrm{O}_{2}$ treatments (Fig. 10c). This 589 agrees with the known stability of chromium nitride structures.

590 In addition to providing knowledge on the oxidation state and co591 ordination chemistry of transition metals, XAS allows quantifying the 592 bulk metal content from the absolute height of the absorption step 593 combined with the exact mass of each pellet used for measurements 594 in transmission mode. Figure 12 shows the bulk content of $\mathrm{Fe}, \mathrm{Co}$ and $595 \mathrm{Cr}$ determined from XAS as a function of the number of $\mathrm{mol}_{2} \mathrm{H}_{2}$ 596 used to treat the catalysts. The bulk contents of $\mathrm{Fe}$ and $\mathrm{Co}$ decreased 597 with increasing amounts of $\mathrm{H}_{2} \mathrm{O}_{2}$. However, the loss is moderate. Af598 ter a treatment with $10^{-2} \mathrm{~mol} \mathrm{H}_{2} \mathrm{O}_{2} \mathrm{mg}^{-1}$, the relative decrease of $599 \mathrm{Fe}$ and Co content was only 17 and $27 \%$, respectively. For $\mathrm{Cr}-\mathrm{N}-\mathrm{C}$, 600 the bulk metal content even increased by $18 \%$, highlighting the better 601 resistance to the peroxide treatment of $\mathrm{CrN}$ particles than the $\mathrm{N}$-doped 602 carbon matrix. Dodelet's group also reported in 2003 a relative loss 603 of $\mathrm{Fe}$ of only $30-40 \%$ after $\mathrm{H}_{2} \mathrm{O}_{2}$ treatment. In parallel, the half-wave 604 potential for ORR in RDE decreased by $150-200 \mathrm{mV}$, corresponding 605 to ca two-order-of-magnitude decrease in ORR activity. ${ }^{25}$ For another 606 Fe-N-C catalyst, Zelenay's group observed a decrease of Fe content 607 from 0.9 to 0.6 at. $\%$ (33\% relative los) after $\mathrm{H}_{2} \mathrm{O}_{2}$ treatment for $60872 \mathrm{~h}$, which was accompanied by a $150 \mathrm{mV}$ downshift of the half609 wave potential for ORR when measured in RDE. ${ }^{26}$ A XANES analysis 610 with linear combination fitting of reference spectra identified that only $61120-25 \%$ of the iron atoms in their pristine catalyst were involved in a $612 \mathrm{Fe}^{\text {II }} \mathrm{Pc}$-like coordination, the remainder being iron sulfide, iron oxide 613 and metallic iron structures. This complicated the identification of a 614 correlation, or lack of correlation, between the decrease in bulk con615 tent of $\mathrm{FeN}_{\mathrm{x}} \mathrm{C}_{\mathrm{y}}$ moieties during $\mathrm{H}_{2} \mathrm{O}_{2}$ treatment and the decrease of 616 ORR activity. Here in contrast, ca 80 and $90 \%$ of the metal atoms in the 617 pristine $\mathrm{Co}-\mathrm{N}-\mathrm{C}$ and $\mathrm{Fe}-\mathrm{N}-\mathrm{C}$ catalysts are assigned to $\mathrm{MeN}_{\mathrm{x}} \mathrm{C}_{\mathrm{y}}$ moi618 eties, respectively (see Structural characterisation of pristine catalysts 619 section and ${ }^{57} \mathrm{Fe}$ Mössbauer spectroscopy on pristine and degraded $620 \mathrm{Fe}-\mathrm{N}-\mathrm{C}$ catalysts section). The relative loss of only 27 and $17 \%$ of $621 \mathrm{Co}$ and $\mathrm{Fe}$ compared to the ORR activity loss measured in RDE after 622 a treatment with $10^{-2}$ mol $\mathrm{H}_{2} \mathrm{O}_{2} \mathrm{mg}^{-1}$ (activity divided by a factor 6236.6 for $\mathrm{Fe}-\mathrm{N}-\mathrm{C}$ and 2.9 for $\mathrm{Co}-\mathrm{N}-\mathrm{C}$ ) suggests that only a fraction of 624 the $\mathrm{Fe}$ and Co atoms in the pristine catalysts are located on the top 625 surface and participate in the ORR. Alternatively, if a major fraction 626 of $\mathrm{MeN}_{\mathrm{x}} \mathrm{C}_{\mathrm{y}}$ moieties is located on the top surface initially, the results 627 suggest that surface oxidation due to $\mathrm{H}_{2} \mathrm{O}_{2}$ drastically reduced the 628 turnover frequency for ORR of the remaining $\mathrm{MeN}_{\mathrm{x}} \mathrm{C}_{\mathrm{y}}$ moieties. In

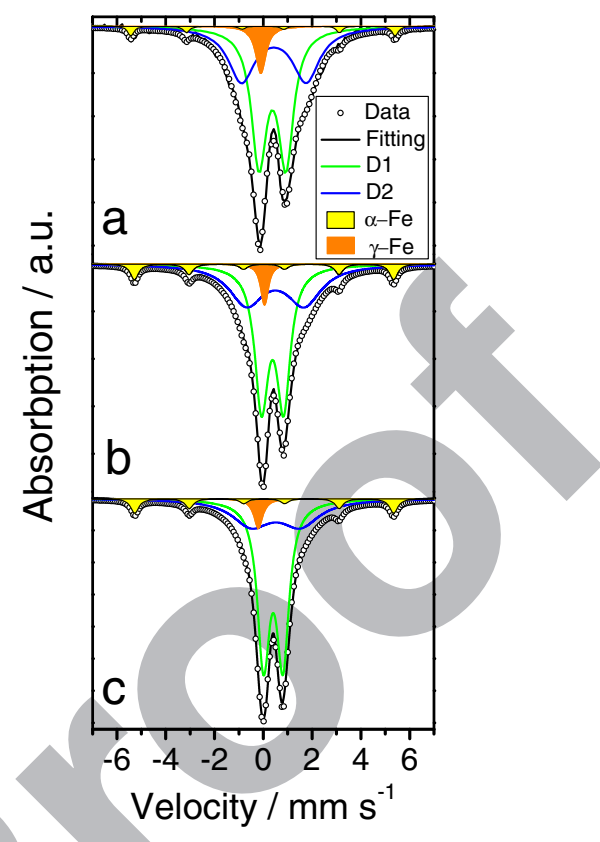

Figure 13. Mössbauer absorption spectra measured for pristine $\mathrm{Fe}-\mathrm{N}-\mathrm{C}$ and after ex situ treatment with $\mathrm{H}_{2} \mathrm{O}_{2}$. a) pristine, b) after $2 \cdot 10^{-3} \mathrm{~mol}_{2} \mathrm{O}_{2} \mathrm{mg}^{-1}$, c) after $10^{-2} \mathrm{~mol} \mathrm{H}_{2} \mathrm{O}_{2} \mathrm{mg}^{-1}$.

this second hypothesis, the fact that little or no modification of the 629 XANES spectra is observed after $\mathrm{H}_{2} \mathrm{O}_{2}$ treatment, especially for $\mathrm{Fe}-630$ $\mathrm{N}-\mathrm{C}$, suggests that the oxidation would have mostly occurred on the 631 $\mathrm{N}$-doped carbon matrix. Preferential oxidation at the edge of graphene 632 sheets could have modified the electronic properties. The latter might 633 in turn have modified the access of electrons to the $\mathrm{MeN}_{\mathrm{x}} \mathrm{C}_{\mathrm{y}}$ moieties. ${ }_{634}$ The latter are believed to be covalently integrated near the edge, or at 635 the edge, of graphene sheets. ${ }^{48,50-55}$ Decreased electronic properties 636 and conductivity at the edge would have profound implications in 637 particular for $\mathrm{MeN}_{\mathrm{x}} \mathrm{C}_{\mathrm{y}}$ moieties located in micropores. ${ }^{56,57}$

${ }^{57} \mathrm{Fe}$ Mössbauer spectroscopy on pristine and degraded $\mathrm{Fe}-\mathrm{N}-\mathrm{C} \quad 639$ catalysts. - Mössbauer spectroscopy is a powerful technique to iden- 640 tify the presence of different iron coordinations in multiphase mate- 641 rials. It is therefore ideally suited to be used alone or in combina- 642 tion with XAS ${ }^{58-60}$ With EXAFS, the secondary peak observed at ca 643 2.1-2.3 $\AA$ in the Fourier-transform may be assigned to backscatter- 644 ing from either carbon atoms in the second coordination sphere of 645 $\mathrm{FeN}_{\mathrm{x}} \mathrm{C}_{\mathrm{y}}$ moieties, or from iron atoms in the first or second coordina- 646 tion sphere of metallic iron or iron carbide (Fig. 3a). The detection 647 of a minor fraction of iron atoms involved in Fe-based crystalline 648 structures is therefore difficult with EXAFS. Figure 13 shows the ${ }^{57} \mathrm{Fe} \quad{ }_{649}$ Mössbauer spectra for pristine Fe-N-C and for samples obtained after 650 its treatment with $2 \cdot 10^{-3}$ and $10^{-2} \mathrm{~mol} \mathrm{H}_{2} \mathrm{O}_{2} \mathrm{mg}^{-1}$. The Mössbauer 651 spectrum of pristine $\mathrm{Fe}-\mathrm{N}-\mathrm{C}$ shows that the major components are the 652 doublets D1 and D2 (Fig. 13a). They have previously been assigned 653 to a square-planar $\mathrm{Fe}^{\mathrm{II}} \mathrm{N}_{4}$ coordination with $\mathrm{Fe}^{\mathrm{II}}$ in low and medium 654 spin, respectively. ${ }^{58-61}$ Doublets D1 has Mössbauer parameters sim- 655 ilar to those of unpyrolyzed $\mathrm{Fe}^{\mathrm{II}} \mathrm{Pc}$ adsorbed on carbon, while D2 ${ }_{656}$ has parameters similar to those of crystalline $\mathrm{Fe}^{\mathrm{II}} \mathrm{Pc}$ in which stacked ${ }_{657}$ molecules interact with each other (Table I). ${ }^{62}$ A sextet and a singlet 658 component are also detected and unambiguously assigned to $\alpha$-Fe and 659 $\gamma$-Fe, respectively (Fig. 13a). ${ }^{63}$ The spectral areas of these two com- 660 ponents represent only 10\% (Table I), demonstrating that the major 661 fraction of iron atoms in pristine $\mathrm{Fe}-\mathrm{N}-\mathrm{C}$ is engaged in molecular-like 662 $\mathrm{FeN}_{\mathrm{x}} \mathrm{C}_{\mathrm{y}}$ moieties. Figures $13 \mathrm{~b}$ and $13 \mathrm{c}$ show the spectra after perox- 663 ide treatment with $2 \cdot 10^{-3}$ and $10^{-2} \mathrm{~mol} \mathrm{H}_{2} \mathrm{O}_{2} \mathrm{mg}^{-1}$, respectively. No 664 major changes are observed. With increasing amount of $\mathrm{H}_{2} \mathrm{O}_{2}$, a trend 665 of increased relative fraction of D1 and decreased relative fraction 666 of D2 is noticed. In parallel, the relative fraction summed for $\alpha-\mathrm{Fe}{ }_{667}$ 
Table I. Mössbauer parameters derived from the fitting with four components of the spectrum for pristine Fe-N-C and for Fe-N-C after ex situ treatment with $2 \cdot 10^{-3}$ and $10^{-2} \mathrm{~mol} \mathrm{H}_{2} \mathrm{O}_{2} \mathrm{mg}^{-1}$. The hyperfine field of the sextet was 33.6, 33.0 and 32.9 $\mathrm{T}$ for pristine Fe-N-C, 2.10 ${ }^{-3}$ and $10^{-2}$ treated Fe-N-C samples, respectively.

Relative Area/\%

\begin{tabular}{ccccccc}
\cline { 2 - 3 } \cline { 5 - 6 } & Pristine & $2 \cdot 10^{-3}$ & $10^{-2}$ & & Pristine & $2 \cdot 10^{-3}$ \\
\hline D1 & $53 \pm 5$ & $51 \pm 2$ & $59 \pm 3$ & & $0.38 \pm 0.01$ & $0.38 \pm 0.00$ \\
D2 & $38 \pm 3$ & $37 \pm 2$ & $29 \pm 2$ & & $0.43 \pm 0.02$ & $0.49 \pm 0.01$ \\
Sextet & $3 \pm 1$ & $7 \pm 0$ & $7 \pm 0$ & & $-0.02 \pm 0.03$ & $0.03 \pm 0.01$ \\
Singlet & $6 \pm 1$ & $4 \pm 0$ & $4 \pm 0$ & & -0.10 fixed & $0.05 \pm 0.01$
\end{tabular}

668 723 ROS. 5 be due to electronic effects of the surrounding carbon support, which
becomes more oxidized and contains fewer delocalized $\pi$ electrons.

717 Hence, either the ORR activity in pristine $\mathrm{Fe}-\mathrm{N}-\mathrm{C}$ is due to a mi718 nor fraction of D1 or D2 sites located on the top surface, or the 719 top surface of the catalyst was highly oxidized during $\mathrm{H}_{2} \mathrm{O}_{2}$ treat720 ment, leading to a loss of surface conductivity or partial exfoliation 721 of the graphene sheets. The latter transformations may be localized 722 around the surface $\mathrm{FeN}_{\mathrm{x}} \mathrm{C}_{\mathrm{y}}$ moieties, where $\mathrm{H}_{2} \mathrm{O}_{2}$ reacted to form

and $\gamma$-Fe increases only from 9 to $11 \%$. Such metallic particles are embedded in a graphitic shell and resist oxidative attacks, as previ-
ously shown in a high-voltage degradation study of the same catalyst. ${ }^{21}$ If a large amount of $\mathrm{FeN}_{\mathrm{x}} \mathrm{C}_{\mathrm{y}}$ moieties had been removed from the catalyst during $\mathrm{H}_{2} \mathrm{O}_{2}$ treatment, the relative fraction of $\alpha$-Fe and $\gamma$-Fe after treatment would have dramatically increased. The fact that it only inreased from 9 to $11 \%(+22 \%$ relative increase $)$ confirms that most of 列 $\mathrm{C}_{\mathrm{y}}$ moieties existing in pristine $\mathrm{Fe}-\mathrm{N}-\mathrm{C}$ are still present after decrease in bulk Fe content, only $17 \%$ relative decrease after treatment with $10^{-2} \mathrm{~mol} \mathrm{H}_{2} \mathrm{O}_{2} \mathrm{mg}^{-1}$ (Fig. 12). Due to the trends of relative area of D1 and D2, it can be concluded that the peroxide treatment entially removed $\mathrm{FeN}_{\mathrm{x}} \mathrm{C}_{\mathrm{y}}$ moieties assigned to D2. The relative not entirely be assigned to the removal of $\mathrm{D} 2$ sites. If this were true, the decrease in the relative area of D2 would have been commensurate with that number. However, it only decreased from 38 to $29 \%$ both the D2 and D1 sites that were initially present in pristine Fe$\mathrm{N}-\mathrm{C}$. These fractions can be estimated mathematically. If one considers $100 \mathrm{Fe}$ atoms in pristine $\mathrm{Fe}-\mathrm{N}-\mathrm{C}$, then $53 \mathrm{Fe}$ atoms are in D1
sites, 38 atoms in $\mathrm{D} 2$ sites and the remainder in metallic structures (Table I). The $\mathrm{H}_{2} \mathrm{O}_{2}$ treatment with $10^{-2} \mathrm{~mol} \mathrm{H}_{2} \mathrm{O}_{2} \mathrm{mg}^{-1}$ removed 17 out of those 100 atoms ( $17 \%$ loss). After trial-and-error calculations, it is found that when, among those $17 \mathrm{Fe}$ atoms, 4 come from D1 the final relative $\%$ of D1 and D2 in the $\mathrm{H}_{2} \mathrm{O}_{2}$ treated sample are $100 \times(53-4) /(100-17)=59 \%$, and $100 \times(38-13) /(100-17)=30 \%$. (hese percentages match those experimentally observed for D1 and decrease in the absolute content of Fe atoms involved in D1 and D2 coordinations upon treatment with $10^{-2} \mathrm{~mol} \mathrm{H}_{2} \mathrm{O}_{2} \mathrm{mg}^{-1}$ can now be calculated. It is ca $100 \times 4 / 53=7.5 \%$ for D 1 , and $100 \times 13 / 38=34 \%$ D2. This information is more precise than the overall loss of $17 \%$ drawn with the decrease in ORR activity for Fe-N-C. After treatwith $10^{-2} \mathrm{~mol} \mathrm{H}_{2} \mathrm{O}_{2} \mathrm{mg}^{-1}$, the latter was divided by 6.6 and by haracterization of pristine and degraded catalysts section).

In conclusion, Mössbauer spectroscopy reveals that most of the $\mathrm{FeN}_{\mathrm{x}} \mathrm{C}_{\mathrm{y}}$ moieties present in pristine $\mathrm{Fe}-\mathrm{N}-\mathrm{C}$ survived the peroxide reatment. The Mössbauer parameters of D1 and D2 were only slightly ing in the peroxide-treated catalysts have an electronic structure and coordination chemistry very similar to those in the pristine catalyst. The apparent continuous decrease of the QS values for D1 and D2 with increased mol $\mathrm{H}_{2} \mathrm{O}_{2} \mathrm{mg}^{-1}$ used for ex situ degradation might be due to electronic effects of the surrounding carbon support, which
$X$-ray photoelectron spectroscopy on pristine and degraded 724 catalysts. - The nitrogen and oxygen content and speciation were in- 725 vestigated with XPS on pristine catalysts as well as on catalysts after 726 treatment with $10^{-2} \mathrm{~mol} \mathrm{H}_{2} \mathrm{O}_{2} \mathrm{mg}^{-1}$. Figure 14 shows as an exam- 727 ple the $\mathrm{N}_{1 \mathrm{~s}}$ narrow scan spectra for the pristine and degraded Fe-N-C $\quad 728$ catalyst. Both experimental spectra were fitted with four components 729 (Table II). They are assigned in the order of increasing binding energy 730 (BE) to pyridinic, pyrrolic, graphitic and oxidized nitrogen. ${ }^{64-67}$ The 731 pyridinic component (BE 398.5-398.7), primarily assigned to $\mathrm{N}$ atoms 732 contributing with one electron to the $\pi$ system, may also comprise $\mathrm{N} 733$ atoms ligating the Fe or Co ions. ${ }^{66-67}$ Next, most pyrrolic $\mathrm{N}$ atoms are 734 expected to be located on the graphene edges, and bonded to two $\mathrm{C} 735$ atoms and $1 \mathrm{H}$ atom in six-membered rings. Third, the graphitic N 736 component comprises all $\mathrm{N}$ atoms bonded with three $\mathrm{C}$-atoms, either 737 within a graphene sheet or at the edge of a graphene sheet. ${ }^{64,68} \quad 738$

From Fig. 14, it can be seen that no novel N-species arose during 739 the treatment of Fe-N-C with $\mathrm{H}_{2} \mathrm{O}_{2}$. This observation holds for Co- 740 $\mathrm{N}-\mathrm{C}$ and $\mathrm{Cr}-\mathrm{N}-\mathrm{C}$. The modified shape of the overall $\mathrm{N}_{1 \mathrm{~s}}$ spectrum in 741 Fe-N-C after degradation is due to a larger relative fraction of pyrrolic- 742 $\mathrm{N}$. After quantification of the atomic $\%$ of $\mathrm{C}, \mathrm{N}$ and $\mathrm{O}$, it is found that 743 the absolute content of pyrrolic $\mathrm{N}$ increased from 1.07 to 1.97 at $\% \quad 744$ during degradation, (Table II). This absolute increase in pyrrolic N 745 is also observed with Co-N-C and Cr-N-C (Table II). In contrast, the 746 absolute content of all other $\mathrm{N}$ species in Fe-N-C, Co-N-C or Cr-N-C 747 was unmodified or increased only slightly after $\mathrm{H}_{2} \mathrm{O}_{2}$ treatment. The 748 exception is the significant decrease of pyridinic $\mathrm{N}$ for $\mathrm{Cr}-\mathrm{N}-\mathrm{C}$ after 749 $\mathrm{H}_{2} \mathrm{O}_{2}$ degradation (ca-1 at \%). The changes observed in the nitrogen 750

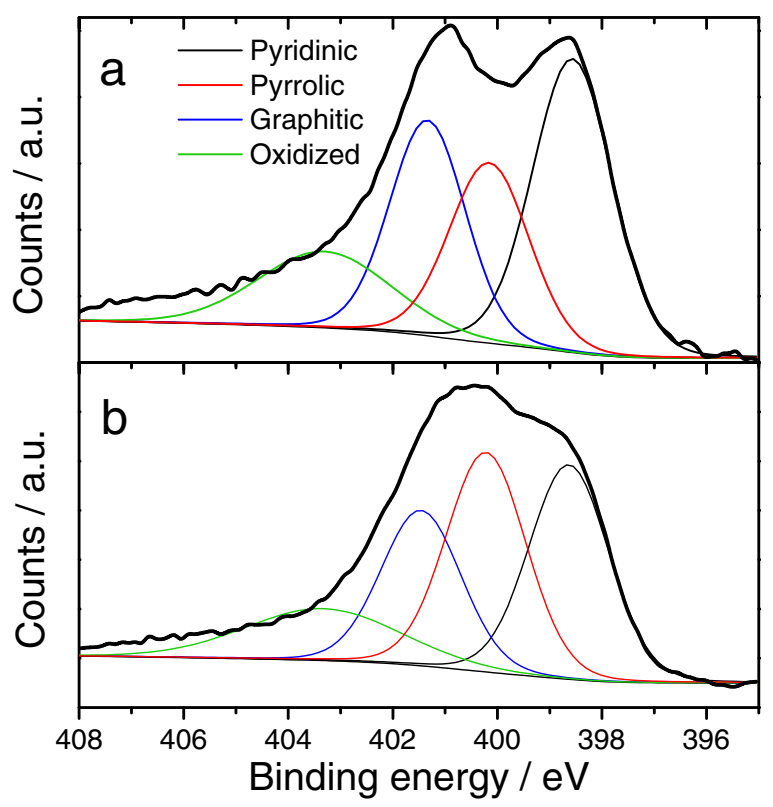

Figure 14. $\mathrm{N}_{1 \mathrm{~s}}$ narrow scan spectra measured with XPS for a) the pristine $\mathrm{Fe}$ $\mathrm{N}-\mathrm{C}$ catalyst and b) the Fe-N-C catalyst treated with $10^{-2} \mathrm{~mol} \mathrm{H}_{2} \mathrm{O}_{2} \mathrm{mg}^{-1}$. The experimental spectra were fitted with four nitrogen components. 
Table II. X-ray photoelectron spectroscopy analysis of the $\mathrm{N}_{1 \mathrm{~s}}$ and $\mathrm{O}_{1 \mathrm{~s}}$ narrow scans for pristine catalysts and catalysts degraded with $10^{-2}$ mol $\mathrm{H}_{2} \mathrm{O}_{2} \mathrm{mg}^{-1}$. For $\mathrm{Cr}-\mathrm{N}-\mathrm{C}$, a fifth $\mathrm{N}$-component at 396.5-396.7 eV assigned to $\mathrm{CrN}$ was present with 0.15 and 0.33 atom $\%$ in the pristine and degraded catalysts, respectively.

\begin{tabular}{|c|c|c|c|c|c|c|c|c|c|c|}
\hline & \multicolumn{5}{|c|}{ Nitrogen } & \multicolumn{5}{|c|}{ Oxygen } \\
\hline & Pyridinic or $\mathrm{MeN}_{\mathrm{x}}$ & Pyrrolic & Graphitc & Oxidized & Total & $\mathrm{O} 1$ & $\mathrm{O} 2$ & $\mathrm{O} 3$ & $\mathrm{O} 4$ & Total \\
\hline $\mathrm{BE}$ range/eV & $398.5-398.7$ & $400.0-400.4$ & $401.3-401.5$ & $403.3-403.7$ & & $530.8-531.2$ & $532.5-532.8$ & $534.2-534.3$ & $536.2-536.7$ & \\
\hline $\mathrm{Fe}-\mathrm{N}-\mathrm{C}$ pristine & 1.75 & 1.07 & 1.21 & 0.76 & 4.8 & 1.14 & 2.64 & 0.70 & 0.12 & 4.6 \\
\hline Fe-N-C degraded & 1.93 & 1.97 & 1.40 & 0.90 & 6.2 & 4.20 & 6.55 & 1.50 & 0.55 & 12.8 \\
\hline Co-N-C pristine & 1.76 & 0.84 & 1.55 & 0.85 & 5.0 & 1.81 & 2.79 & 0.47 & 0.13 & 5.2 \\
\hline Co-N-C degraded & 2.20 & 1.46 & 1.54 & 0.90 & 6.1 & 2.79 & 5.40 & 1.00 & 0.32 & 9.5 \\
\hline $\mathrm{Cr}-\mathrm{N}-\mathrm{C}$ pristine & 3.08 & 1.25 & 1.43 & 0.79 & 6.7 & 3.54 & 2.79 & 0.48 & 0.39 & 7.2 \\
\hline $\mathrm{Cr}-\mathrm{N}-\mathrm{C}$ degraded & 2.02 & 2.10 & 1.28 & 0.57 & 6.3 & 5.11 & 6.22 & 1. & 0.93 & 13.5 \\
\hline
\end{tabular}

751 speciation for Fe-N-C and Co-N-C are now discussed in parallel, due 752 to their similar active site structure. As a result of increased pyrrolic $753 \mathrm{~N}$ and unmodified content of other $\mathrm{N}$-species, the absolute $\mathrm{N}$ content 754 increased by $1.1-1.4$ at $\%$ after the peroxide treatment of $\mathrm{Fe}-\mathrm{N}-\mathrm{C}$ and 755 Co-N-C (Table II). This is counter-intuitive. The least stable carbon 756 atoms must have been substituted by nitrogen atoms from $\mathrm{N}_{2}$ in air, a 757 substitution that might have been catalyzed by ROS. Increased content 758 of nitrogen was previously observed by Zelenay's group after ex situ $759 \mathrm{H}_{2} \mathrm{O}_{2}$ treatment of another Fe-N-C catalyst. ${ }^{26}$ In that study, after a 760 sharp drop from 6 to 3 at $\% \mathrm{~N}$ after $24 \mathrm{~h}$ of immersion in a $10 \% \mathrm{H}_{2} \mathrm{O}_{2}$ 761 solution (unmodified ORR activity), the N-content steadily increased 762 from 3.0 to 3.5 at $\%$ after $24-100 \mathrm{~h}$ of immersion (negative shift of $763200 \mathrm{mV}$ for the ORR half-wave potential measured with RDE). In 764 that study, the $\mathrm{H}_{2} \mathrm{O}_{2}$ treatment corresponds to $1.5-10^{-2}$ mol $\mathrm{H}_{2} \mathrm{O}_{2}$ $765 \mathrm{mg}^{-1}$ and was also performed at $80^{\circ} \mathrm{C} .^{26,69}$ The $\mathrm{N}$-speciation after ex 766 situ $\mathrm{H}_{2} \mathrm{O}_{2}$ treatment was not discussed, but after fuel cell testing for $767500 \mathrm{~h}$ a relative increase in pyrrolic $\mathrm{N}$ was also observed on the $\mathrm{N}_{1 \mathrm{~s}}$ 768 spectrum. $^{26}$

769 Changes in the $\mathrm{N}$ content and speciation of the Cr-N-C catalysts 770 are now discussed. For $\mathrm{Cr}-\mathrm{N}-\mathrm{C}$, a fifth $\mathrm{N}$ component was necessary 771 for fitting the $\mathrm{N}_{1 \mathrm{~s}}$ spectrum. Its $\mathrm{BE}$ of 396.5-396.7 eV corresponds 772 to $\mathrm{CrN}^{70}$ The small $\mathrm{N}$ content assigned to $\mathrm{CrN}$ is explained on the 773 basis of the smaller penetration depth of X-rays in CrN (Table II). 774 Thus, the $\mathrm{N}_{1 \mathrm{~s}}$ spectrum of $\mathrm{Cr}-\mathrm{N}-\mathrm{C}$ is practically unmodified by the 775 presence of $\mathrm{CrN}$ and largely reflects $\mathrm{N}$-moieties integrated in the 776 carbon matrix. While pristine $\mathrm{Cr}-\mathrm{N}-\mathrm{C}$ shows contents of pyrrolic, 777 graphitic and oxidized N similar to those of pristine $\mathrm{Fe}-\mathrm{N}-\mathrm{C}$ and $\mathrm{Co}-$

$778 \mathrm{~N}-\mathrm{C}$, its content of pyridinic $\mathrm{N}$ is significantly higher, 3.08 vs. 1.75 Q1 779 at \% for Fe- and Co-N-C (Table III). Similar to Fe- and Co-N-C, 780 the content of pyrrolic $\mathrm{N}$ in $\mathrm{Cr}-\mathrm{N}-\mathrm{C}$ increased after $\mathrm{H}_{2} \mathrm{O}_{2}$ treatment $781(+0.85$ at \%). In contrast to $\mathrm{Fe}-$ and $\mathrm{Co}-\mathrm{N}-\mathrm{C}$, the content of pyridinic $782 \mathrm{~N}$ decreased strongly $(-1.06$ at \%). Since $\mathrm{CrN}$ particles are not known 783 to be active toward ORR, the activity of $\mathrm{Cr}-\mathrm{N}-\mathrm{C}$ is assigned to highly 784 basic $\mathrm{N}$-groups formed in the carbon matrix during $\mathrm{NH}_{3}$ pyrolysis. ${ }^{16,58}$ 785 The strong decrease of pyridinic $\mathrm{N}$ in $\mathrm{Cr}-\mathrm{N}-\mathrm{C}$ with $\mathrm{H}_{2} \mathrm{O}_{2}$ treatment 786 might explain the strong decrease in ORR activity of that catalyst after $787 \mathrm{H}_{2} \mathrm{O}_{2}$ treatment (Fig. 4c).

788 The oxygen content and speciation is now discussed (Table II). 789 The total O-content increased dramatically after $\mathrm{H}_{2} \mathrm{O}_{2}$ treatment for $790 \mathrm{Fe}-\mathrm{N}-\mathrm{C}(+8.2$ at \%), Co-N-C $(+4.3$ at \%) and $\mathrm{Cr}-\mathrm{N}-\mathrm{C}(+6.3$ at \%). 791 The larger increase of O-content in Fe-N-C vs. Co-N-C is positively 792 correlated with a larger decrease in ORR activity (Figs. $5 \& 7$ ). The $793 \mathrm{O}_{1 \mathrm{~s}}$ spectra were fitted with four components, labelled O1 to O4 794 (Table II). The $\mathrm{O} 1$ component is assigned to oxygen doubly bonded 795 with $\mathrm{C}$ as in $\mathrm{C}=\mathrm{O}$ or $\mathrm{O}=\mathrm{C}-\mathrm{OH}, \mathrm{O} 2$ is assigned to $\mathrm{C}-\mathrm{O}-\mathrm{H}$ or $\mathrm{C}-\mathrm{O}-\mathrm{C}$ 796 groups and $\mathrm{O} 3$ to oxygen singly-bonded with $\mathrm{C}$ as in $\mathrm{O}=\mathrm{C}-\mathrm{OH}$ or $797 \mathrm{O}=\mathrm{C}-\mathrm{OR} .{ }^{71}$ The increase of the $\mathrm{O} 1$ and $\mathrm{O} 2$ components in $\mathrm{Fe}-\mathrm{N}-\mathrm{C}$, $798 \mathrm{Co}-\mathrm{N}-\mathrm{C}$ and $\mathrm{Cr}-\mathrm{N}-\mathrm{C}$ accounts for the major part of the total increase 799 in $\mathrm{O}$-content after $\mathrm{H}_{2} \mathrm{O}_{2}$ treatment. The largest increase is observed 800 for C-O-H (hydroxyl) and C-O-C (epoxide). Those groups are known 801 to result in strong distortion of the graphene layers due to $\mathrm{sp}^{3}$ hy-

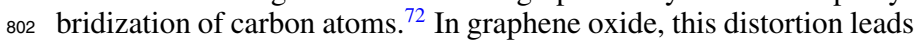
803 to a interlayer spacing of $6.7 \AA$, ca twice that in graphite. ${ }^{73}$ The in- crease in total O-content on Fe-N-C after treatment with $10^{-2}$ mol 804 $\mathrm{H}_{2} \mathrm{O}_{2} \mathrm{mg}^{-1}(+8.4$ at $\%)$ is very similar to the value of +8.0 at $\% 805$ oxygen reported for a PANI-Fe-C catalyst over a $500 \mathrm{~h}$ PEMFC test 806 at $0.4 \mathrm{~V}^{26}$ Surface oxidation of carbon thus seems to be the main 807 degradation route during reaction with $\mathrm{H}_{2} \mathrm{O}_{2}$. The inclusion of large 808 amounts of oxygen on the edge of graphene sheets or on the basal 809 planes may have dramatically changed the electronic properties of 810 the surface, as reported for graphene nano-ribbons. ${ }^{74-75}$ The Co-N-C 811 catalyst was however less oxidized than $\mathrm{Fe}-\mathrm{N}-\mathrm{C}$ and $\mathrm{Cr}-\mathrm{N}-\mathrm{C}$ after 812 treatment with $10^{-2} \mathrm{~mol} \mathrm{H}_{2} \mathrm{O}_{2} \mathrm{mg}^{-1}$. This agrees with the trends 813 in fluoride measurement and collection yield previously discussed 814 (Fig. 9). For Co-N-C, the weight gain of $6 \%$ observed after treat- 815 ment with $10^{-2} \mathrm{~mol} \mathrm{H}_{2} \mathrm{O}_{2} \mathrm{mg}^{-1}$ is commensurate with the increase in 816 $\mathrm{O}$-content measured by XPS $(+4.3$ at. \%). Hence, it seems that no car- 817 bon atoms initially present in $\mathrm{Co}-\mathrm{N}-\mathrm{C}$ were lost during the treatment 818 with $10^{-2} \mathrm{~mol} \mathrm{H}_{2} \mathrm{O}_{2} \mathrm{mg}^{-1}$, and oxygen atoms grafted on the catalyst 819 surface.

Comparison between ex situ $\mathrm{H}_{2} \mathrm{O}_{2}$ degradation and operando fuel 821 cell degradation.- In this section, we focus on the Fe-N-C catalyst. 822 The polarization curves of a PEMFC with a loading of $4 \mathrm{mg} \mathrm{cm}^{-2}$ of 823 pristine $\mathrm{Fe}-\mathrm{N}-\mathrm{C}$ at the cathode have been recorded at $\mathrm{BoL}$ and after 824 different duration of galvanostatic operation at $0.5 \mathrm{~A} \mathrm{~cm}^{-2}$ (Fig. 15, 825 solid lines). A galvanostatic control was chosen in order to easily 826 calculate the electric charge that passed through the cathode. The ${ }_{827}$ polarization curves measured at $\mathrm{BoL}$ of cathodes comprising $\mathrm{Fe}-\mathrm{N}-{ }_{828}$ $\mathrm{C}$ catalysts after treatment with $\mathrm{H}_{2} \mathrm{O}_{2}$ are also shown (dashed and 829 dashed-dot curves). As can be seen, the BoL curve for Fe-N-C treated 830 with $10^{-2} \mathrm{~mol} \mathrm{H}_{2} \mathrm{O}_{2}$ per mg corresponds to ca $76-100 \mathrm{~h}$ of operation 831

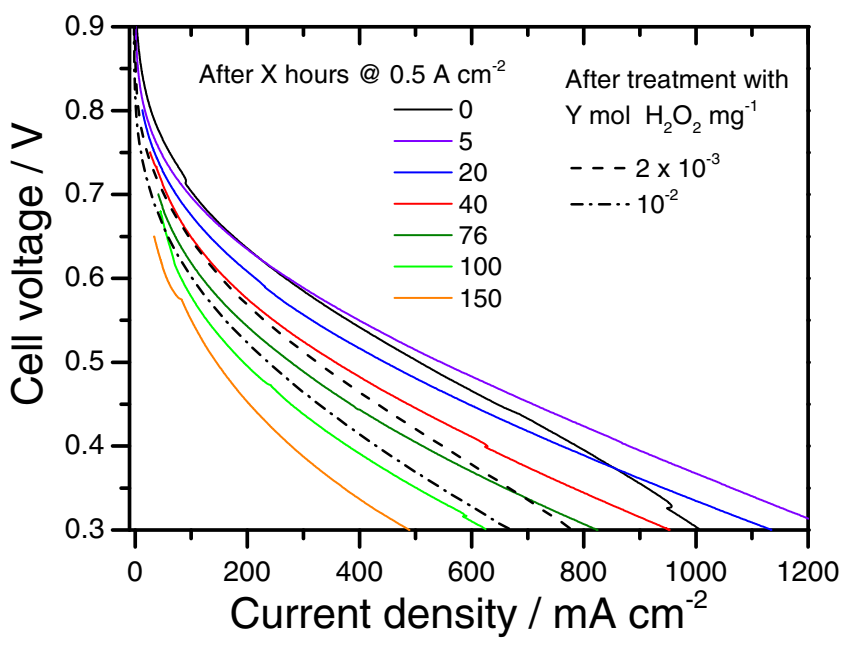

Figure 15. PEMFC polarization curves for cathodes comprising the pristine $\mathrm{Fe}-\mathrm{N}-\mathrm{C}$ and measured after $\mathrm{X}$ hours of operation in fuel cell at $0.5 \mathrm{~A} \mathrm{~cm}^{-2}$ (solid lines) and for cathodes comprising Fe-N-C catalysts treated with Y mol $\mathrm{H}_{2} \mathrm{O}_{2}$ per mg and measured at BoL (dashed or dash-dot lines). 
832 in fuel cell at $0.5 \mathrm{~A} \mathrm{~cm}^{-2}$. If $\mathrm{H}_{2} \mathrm{O}_{2}$ released during ORR in fuel cell is 833 the most important cause of degradation under steady state operation, 834 the cumulative amount of $\mathrm{H}_{2} \mathrm{O}_{2}$ produced after $76-100 \mathrm{~h}$ at $0.5 \mathrm{~A}$ $835 \mathrm{~cm}^{-2}$ and normalized by the mass of catalyst in the cathode should be 836 similar to the amount of $10^{-2} \mathrm{~mol} \mathrm{H}_{2} \mathrm{O}_{2}$ per mg used for the ex situ 837 degradation. The calculation of that scalar for operando conditions 838 now only requires a hypothesis on the $\% \mathrm{H}_{2} \mathrm{O}_{2}$ produced during ORR 839 on the $\mathrm{Fe}-\mathrm{N}-\mathrm{C}$ catalyst. This $\% \mathrm{H}_{2} \mathrm{O}_{2}$ can be assumed on the basis of 840 the RRDE measurements on pristine Fe-N-C (Fig. 6).

841 To calculate the cumulative number of $\mathrm{mol} \mathrm{H}_{2} \mathrm{O}_{2}$ produced in fuel 842 cell after $\mathrm{X}$ hours, we now derive its expression as a function of the 843 steady-state current density of the fuel cell, the duration of operation 844 and the $\% \mathrm{H}_{2} \mathrm{O}_{2}$ during ORR. When the PEMFC operates at $0.5 \mathrm{~A}$ $845 \mathrm{~cm}^{-2}$ with a cathode catalyst loading of $4 \mathrm{mg} \mathrm{cm}^{-2}$, then the electric 846 current produced by every $\mathrm{mg}$ of catalyst is $0.5 / 4=0.125 \mathrm{~A}$. After 847 e.g. $100 \mathrm{~h}$ of operation, the electric charge passed per mg of catalyst is $848100 \times 3600 \times 0.125=4.5 \times 10^{4} \mathrm{C} \mathrm{mg}^{-1}$, equivalent to $0.466 \mathrm{~mol}$ of 849 electrons per $\mathrm{mg}$ of catalyst. If the $\% \mathrm{H}_{2} \mathrm{O}_{2}$ produced as a by-product 850 of the ORR is $5 \%\left(5 \mathrm{~mol} \mathrm{H}_{2} \mathrm{O}_{2}\right.$ produced for $100 \mathrm{~mol}$ of reacted $\mathrm{O}_{2}$ ), 851 then it ensues that $5 \mathrm{~mol} \mathrm{H}_{2} \mathrm{O}_{2}$ are produced for $390 \mathrm{~mol}$ of electrons. 852 The latter scalar comes from 5 mol $\mathrm{H}_{2} \mathrm{O}_{2} \times 2$ electrons $/ \mathrm{H}_{2} \mathrm{O}_{2}+95$ $853 \mathrm{~mol} \mathrm{H}_{2} \mathrm{O} \times 4$ electrons $/ \mathrm{H}_{2} \mathrm{O}$. The scalar of $0.466 \mathrm{~mol}$ electrons per $854 \mathrm{mg}$ can now be converted to the scalar $\mathrm{mol} \mathrm{H}_{2} \mathrm{O}_{2}$ per mg catalyst by 855 multiplying it by $5 / 390$. This yields $5.97 \times 10^{-3} \mathrm{~mol} \mathrm{H}_{2} \mathrm{O}_{2}$ per mg. It 856 represents the number of $\mathrm{mol} \mathrm{H}_{2} \mathrm{O}_{2}$ that $1 \mathrm{mg}$ of $\mathrm{Fe}-\mathrm{N}-\mathrm{C}$ catalyst has 857 produced over $100 \mathrm{~h}$ of operation at $0.5 \mathrm{~A} \mathrm{~cm}^{-2}$. Based on the above 858 reasoning, the general equation relating the $\% \mathrm{H}_{2} \mathrm{O}_{2}(\mathrm{x})$ during ORR 859 with the ratio mole $\mathrm{H}_{2} \mathrm{O}_{2}$ per mol of electrons is:

$$
\mathrm{mol} \mathrm{H}_{2} \mathrm{O}_{2} / \text { mol electrons }=\mathrm{R} 1=\mathrm{x} /(400-2 \mathrm{x})
$$

860 Also, the general relation between the current density, I, duration of 861 PEMFC operation at that current density, $\Delta \mathrm{t}$, and the ratio of mol 862 electrons per $\mathrm{mg}$ catalyst is:

$$
\text { mol electrons } / \mathrm{mg} \text { catalyst }=\mathrm{R} 2=\mathrm{I} \Delta \mathrm{t} /(\mathrm{FL})
$$

863 Where $\mathrm{I}$ is the current density in $\mathrm{A} \mathrm{cm}^{-2}, \Delta \mathrm{t}$ is the duration in seconds, 864 F Faraday's constant in S.I. units and L the cathode catalyst loading 865 in $\mathrm{mg} \mathrm{cm}^{-2}$. From equations 1 and 2, the ratio of $\mathrm{mol}_{2} \mathrm{O}_{2}$ per $\mathrm{mg}$ 866 catalyst can be expressed as:

$$
\mathrm{mol} \mathrm{H}_{2} \mathrm{O}_{2} \text { per mg catalyst }=\mathrm{R} 1 \cdot \mathrm{R} 2=\mathrm{x} \mathrm{I} \Delta \mathrm{t} /[\mathrm{FL}(400-2 \mathrm{x})]
$$

867 Applying this equation with $\mathrm{x}=5, \mathrm{I}=0.5 \mathrm{~A} \mathrm{~cm}^{-2}, \Delta \mathrm{t}=76 \mathrm{~h}$ 868 or $100 \mathrm{~h}$ and $\mathrm{L}=4 \mathrm{mg} \mathrm{cm}^{-2}$, the scalars of $4.5 \cdot 10^{-3}$ and $6 \cdot 10^{-3}$ $869 \mathrm{~mol} \mathrm{H}_{2} \mathrm{O}_{2}$ per mg catalyst are calculated. The fair agreement between 870 polarisation curves measured after $100 \mathrm{~h}$ of operation and that for the $871 \mathrm{Fe}-\mathrm{N}-\mathrm{C}$ catalyst treated with $10^{-2} \mathrm{~mol} \mathrm{H}_{2} \mathrm{O}_{2}$ per $\mathrm{mg}$ catalyst suggests 872 that the formation of $5 \% \mathrm{H}_{2} \mathrm{O}_{2}$ as a by-product of ORR is a possible 873 explanation for the degradation of the $\mathrm{Fe}-\mathrm{N}-\mathrm{C}$ catalyst under relatively 874 high load $\left(0.5 \mathrm{~A} \mathrm{~cm}^{-2}\right)$. The hypothesis of $5 \% \mathrm{H}_{2} \mathrm{O}_{2}$ during ORR in 875 PEMFC is not contradicting the RRDE measurements performed on 876 pristine $\mathrm{Fe}-\mathrm{N}-\mathrm{C}$ (Fig. 6). The $\% \mathrm{H}_{2} \mathrm{O}_{2}$ measured at low loading in 877 RRDE varied between 2.5 and $3.3 \%$ in the range of $0.2-0.5 \mathrm{~V}$ vs. 878 RHE. In conclusion, for Fe-N-C, the scalar mol $\mathrm{H}_{2} \mathrm{O}_{2}$ per mg catalyst 879 predicts both the ex situ and the operando degradation. The underlying 880 cause of the degradation is however believed to be the formation of 881 ROS from the decomposition of $\mathrm{H}_{2} \mathrm{O}_{2}$ on $\mathrm{FeN}_{\mathrm{x}} \mathrm{C}_{\mathrm{y}}$ moieties.

\section{Conclusions}

8 ${ }_{884} \mathrm{C}$ catalyst was investigated. The negative effect on the ORR activity 885 and fuel cell performance was worse for $\mathrm{Cr}-\mathrm{N}-\mathrm{C}$, followed by $\mathrm{Fe}-\mathrm{N}$ ${ }_{886} \mathrm{C}$ and least for Co-N-C. The initial activity of $\mathrm{Cr}-\mathrm{N}-\mathrm{C}$ is assigned 887 to surface $\mathrm{N}$-groups while the initial activity of $\mathrm{Fe}-\mathrm{N}-\mathrm{C}$ and $\mathrm{Co}-\mathrm{N}$ ${ }_{888} \mathrm{C}$ is assigned to $\mathrm{MeN}_{\mathrm{x}} \mathrm{C}_{\mathrm{y}}$ moieties integrated in the carbon matrix. 889 These moieties accounted for ca 80 and $90 \%$ of the metal atoms in the 890 pristine $\mathrm{Co}-$ and $\mathrm{Fe}-\mathrm{N}-\mathrm{C}$ catalysts, respectively. The changes observed 891 with X-ray absorption and Mössbauer spectroscopy before and after 892 degradation with $\mathrm{H}_{2} \mathrm{O}_{2}$ were minor. Most of the $\mathrm{MeN}_{\mathrm{x}} \mathrm{C}_{\mathrm{y}}$ moieties present in the pristine catalysts were still present in the $\mathrm{Fe}-$ and $\mathrm{Co}-\mathrm{N}-{ }_{893}$ $\mathrm{C}$ catalysts after degradation with $10^{-2} \mathrm{~mol} \mathrm{H}_{2} \mathrm{O}_{2} \mathrm{mg}^{-1}$. The relative 894 loss of $\mathrm{Fe}$ and Co content was 17 and $27 \%$. In parallel, the ORR activity 895 at $0.8 \mathrm{~V}$ vs. RHE was divided by ca $6-10$ for $\mathrm{Fe}-\mathrm{N}-\mathrm{C}$ and 3 for $\mathrm{Co}-\mathrm{N}-896$ C. The super-proportional decrease of ORR activity with decreased 897 metal content can be interpreted in two ways: either only a fraction of 898 the $\mathrm{MeN}_{\mathrm{x}} \mathrm{C}_{\mathrm{y}}$ moieties are on the top surface in pristine catalysts, or the 899 turnover frequency for ORR of the $\mathrm{MeN}_{\mathrm{x}} \mathrm{C}_{\mathrm{y}}$ moieties remaining after 900 degradation with $\mathrm{H}_{2} \mathrm{O}_{2}$ was drastically decreased. A technique able to 901 distinguish between $\mathrm{MeN}_{\mathrm{x}} \mathrm{C}_{\mathrm{y}}$ moieties situated in the bulk and those 902 located on the surface is needed to draw final a conclusion. The $\mathrm{H}_{2} \mathrm{O}_{2} \quad 903$ chemical treatment oxidized the surface of the catalysts, resulting 904 in +4 to +8 atom $\%$ oxygen. The oxidizing species is believed to 905 be radical oxygen species (ROS) generated via a Fenton reaction 906 between transition metal centres and $\mathrm{H}_{2} \mathrm{O}_{2}$. This is supported by the 907 lower fluoride concentration and lower degradation measured for Co- 908 $\mathrm{N}-\mathrm{C}$ than for $\mathrm{Fe}-\mathrm{N}-\mathrm{C}$ after peroxide treatment. From a comparison 909 between ex situ and operando degradation, the chemical attack of 910 $\mathrm{Fe}-\mathrm{N}-\mathrm{C}$ by $\mathrm{H}_{2} \mathrm{O}_{2}$ seems to be the main degradation mechanism in 911 steady-state operation. To mitigate this main degradation mechanism, 912 four approaches can be envisaged for Me-N-C catalysts: i) synthesis 913 of catalysts with minimized $\% \mathrm{H}_{2} \mathrm{O}_{2}$ during oxygen reduction, ii) 914 synthesis of catalysts or cathodes with a more graphitic structure, iii) 915 synthesis of catalysts that do not form ROS in the presence of $\mathrm{H}_{2} \mathrm{O}_{2}, \quad 916$ iv) addition of radical scavengers.

\section{Acknowledgments}

918

We acknowledge funding from ANR, contract 2011 CHEX 004919 01 and Synchrotron SOLEIL (Gif-sur Yvette, France) for provision 920 of synchrotron radiation facilities at beamline SAMBA (proposal 921 20131078). Moulay Sougrati (UMR 5253, Montpellier) is acknowl- 922 edged for analysis of the Mössbauer spectra.

923

\section{References}

1. M. Debe, Nature, 486, 43 (2012).

2. F. Jaouen, E. Proietti, M. Lefèvre, R. Chenitz, J. P. Dodelet, G. Wu, H. T. Chung, C. M. Johnston, and P. Zelenay, Energy Environ. Sci., 4, 114 (2011).

3. F. T. Wagner, B. Lakshmanan, and M. F. Mathias, J. Phys. Chem. Lett., 1, 2204 (2010).

4. A. Rabis, P. Rodriguez, and T. J. Schmidt, ACS Catal., 2, 864 (2012).

5. H. A. Gasteiger, S. S. Kocha, B. Sompalli, and F. T. Wagner, Appl. Catal. B-Environ. 56, 9 (2005).

6. B. D. James, J. A. Kalinoski, and K. N. Baum, http://www1.eere.energy.gov/ hydrogenandfuelcells/pdfs/dti_80kwW_fc_system_cost_analysis_report_2010.pdf, accessed 11-11-2012

7. R. Jasinski, Nature, 201, 1212 (1964)

8. M. Lefèvre, E. Proietti, F. Jaouen, and J. P. Dodelet, Science, 324, 71 (2009).

9. E. Proietti, F. Jaouen, M. Lefèvre, N. Larouche, J. Tian, J. Herranz, and J. P. Dodelet, Nature Commun., 2, 416 (2011).

10. G. Wu, K. L. More, C. M. Johnston, and P. Zelenay, Science, 332, 443 (2011).

11. D. Zhao, J.-L. Shui, L. R. Grabstanowicz, C. Chen, S. M. Commet, T. Xu, J. Lu, and D. J. Liu, Adv. Mater., 26, 1093 (2014).

12. S.-T. Chang, C.-H. Wang, H.-Y. Du, H.-C. Hsu, C.-M. Kang, C.-C. Chen, C.-S. Wu, S.-C. Yen, W.-F. Huang, L.-C. Chen, M.-C. Lin, and K.-H. Chen, Energy Environ. Sci., 5, 5305 (2012).

13. J. Tian, A. Morozan, M. T. Sougrati, M. Lefèvre, R. Chenitz, J. P. Dodelet, D. Jones, and F. Jaouen, Angew. Chem. Int. Ed., 52, 6867 (2013).

14. A. Serov, K. Artyushkova, and P. Atanassov, Adv. Energy Mater, 4, 1301735 (2014)

15. N. Larouche, R. Chenitz, M. Lefèvre, E. Proietti, and J. P. Dodelet, Electrochim. Acta, 115, 170 (2014)

16. J. Herranz, F. Jaouen, M. Lefèvre, U. I. Kramm, E. Proietti, J. P. Dodelet, P. Bogdanoff, S. Fiechter, I. Abs-wurmbach, P. Bertrand, T. M. Arruda, and S. Mukerjee, J. Phys. Chem. C, 115, 16087 (2011).

17. M. Ferrandon, J. A. Kropf, D. J. Myers, K. Artyushkova, U. I. Kramm, P. Bogdanoff, G. Wu, C. M. Johnston, and P. Zelenay, J. Phys. Chem. C, 116, 16001 (2012).

18. T. Han, N. Dale, K. Adjemian, V. Nallathambi, and S. C. Barton, Electrochem. Soc. Trans., 41, 2289 (2011).

19. G. Liu, X. Li, P. Ganesan, and B. N. Popov, Appl. Catal. B-Environ., 93, 156 (2009).

20. G. Liu, X. Li, and B. N. Popov, Electrochem. Soc. Trans., 25, 1251 (2009).

21. V. Goellner, C. Baldizzone, A. Schuppert, M. T. Sougrati, K. J. J. Mayrhofer, and F. Jaouen, Phys. Chem. Chem. Phys., 16, 18454 (2014).

22. U. I. Kramm, M. Lefèvre, P. Bogdanoff, D. Schmeisser, and J. P. Dodelet, J. Phys. Chem. Lett., 5, 3750 (2014).

23. F. Charreteur, F. Jaouen, and J. P. Dodelet, Electrochim. Acta, 54, 6622 (2009).
924 925 926 929 930 931
932 933 934 935 936 937 938 939 941 942 944 945 946 948 949 950 951 952 954 955 956 957 958 959 960 961 962 963 
964 24. S. Baranton, C. Coutanceau, C. Roux, F. Hahn, and J. M. Léger, J. Electroanal. Chem., 577, 223 (2005).

966 25. M. Lefèvre and J. P. Dodelet, Electrochim. Acta, 48, 2749 (2003).

967 26. G. Wu, K. Artyushkova, M. Ferrandon, J. Kropf, D. Myers, and P. Zelenay, Electrochem. Soc. Trans., 25, 1299 (2009).

27. A. Muthukrishnan, Y. Nabae, T. Hayakawa, T. Okajima, and T. Ohsaka, Catal. Sci. Technol., 5, 475 (2015).

28. M. Ferrandon, X. Wang, J. Kropf, D. Myers, G. Wu, C. M. Johnston, and P. Zelenay, Electrochim. Acta, 110, 282 (2013)

29. U. I. Kramm, I. Herrmann-Geppert, S. Fiechter, G. Zehl, I. Zizak, I. Dorbandt, D. Schmeisser, and P. Bogdanoff, J. Mater. Chem. A, 2, 2663 (2014).

30. Z. Siroma, N. Fujiwara, T. Ioroi, S.-I. Yamazaki, H. Senoh, K. Yasuda, and K. Tanimoto, J. Power Sources, 172, 155 (2007).

31. J. P. Meyers and R. M. Darling, J. Electrochem. Soc., 153, A1432 (2006).

32. C. A. Reiser, L. Bregoli, T. W. Patterson, J. S. Yi, D. Yang, M. L. Perry, and T. D. Jarvi, Electrochem. Solid State Lett., 8, A273 (2005).

33. F. Jaouen and J. P. Dodelet, J. Phys. Chem. C, 113, 15422 (2009).

34. N. Ramaswamy and S. Mukerjee, Adv. Phys. Chem., 2012, 491604 (2012)

35. J. Chlistunoff, J. Phys. Chem. C, 115, 6496 (2011).

36. J. D. Wiggins-Camacho and K. J. Stevenson, J. Phys. Chem. C, 115, 20002 (2011).

84 37. I. Katsounaros, W. B. Schneider, J. C. Meier, U. Benedikt, U. P. Biedermann, A. A. Auer, and K. J. J. Mayrhofer, Phys. Chem. Chem. Phys., 14, 7384 (2012).

38. F. Haber and J. Weiss, Proceedings of the Royal Society of London. Series A, Mathematical and Physical Sciences, 147, 332 (1934).

39. I. M. Kolthoff and A. I. Medalia, J. Am. Chem. Soc., 71, 3777 (1949).

40. W. G. Barb, J. H. Baxendale, P. George, and K. R. Hargrave, Faraday discussions, 47, $462(1951)$.

41. K. Wiesener, Electrochim. Acta, 31, 1073 (1986).

42. F. H. Lu and H. Y. Chen, Thin solid films, 398, 368 (2001).

43. M. Sevilla and A. B. Fuertes, Carbon, 44, 468 (2006).

94 44. F. J. Maldonado-Hódar, C. Moreno-Castilla, J. Rivera-Utrilla, Y. Hanzawa, and Y. Yamada, Langmuir, 16, 4367 (2000).

45. A. Zitolo, V. Goellner, F. Emiliano, M. T. Sougrati, L. Stievano, and F. Jaouen, submitted (2015)

46. J. M. Ziegelbauer, T. S. Olson, S. Pylypenko, F. Alamgir, C. Jaye, P. Atanassov, and S. Mukerjee, J. Phys. Chem. C, 112, 8839 (2008).

47. F. Jaouen, in Non-noble metal fuel cell catalysts, Wiley -VCH, Weinheim (2014) 29

48. N. Ramaswamy, U. Tylus, Q. Jia, and S. Mukerjee, J. Am. Chem. Soc., 135, 15443 (2013).

49. A. Bonakdarpour, M. Lefèvre, R. Yang, F. Jaouen, T. Dahn, J. P. Dodelet, and J. R. Dahn, Electrochem. Solid-State Lett., 11, B105 (2008).

5 50. E. F. Holby, G. Wu, P. Zelenay, and C. D. Taylor, J. Phys. Chem. C, 118, 14388 (2014)
51. C. E. Szakacs, M. Lefèvre, U. I. Kramm, J. P. Dodelet, and F Vidal, Phys. Chem Chem. Phys., 16, 13654 (2014).

52. E. F. Holby and C. D. Taylor, Appl. Phys. Lett., 101, 064102 (2012).

53. S. Kattel and G. Wang, J. Materials Chem. A, 1, 10790 (2013).

54. S. Kattel, P. Atanassov, and B. Kiefer, Phys. Chem. Chem. Phys., 15, 148 (2013).

55. J. Sun, Y.-H. Fang, and Z.-P. Liu, Phys. Chem. Chem. Phys., 16, 13733 (2014)

7. F. Charreteur, F. Jaouen, S. Ruggeri, and J. P. Dodelet, Electrochim. Acta, 53, 29251014 (2008).

58. U. I. Kramm, J. Herranz, N. Larouche, T. M. Arruda, M. Lefèvre, F. Jaouen, 1016 P. Bogdanoff, S. Fiechter, I. Abs-Wurmbach, S. Mukerjee, and J. P. Dodelet, Phys. 1017 Chem. Chem. Phys., 14, 11673 (2012).

59. U. I. Koslowski, I. Abs-wurmbach, S. Fiechter, and P. Bogdanoff, J. Phys. Chem. C, 1019 112, $15356(2008)$

60. A. Morozan, M. T. Sougrati, V. Goellner, D. Jones, L. Stievano, and F. Jaouen, 102 Electrochim. Acta, 119, 192 (2014).

61. U. I. Kramm, I. abs-Wurmbach, I. Herrmann-Geppert, J. Radnik, S. Fiechter, and 1023 P. Bogdanoff, J. Electrochem. Soc., 158, B69 (2011).

62. C. A. Melendres, J. Phys. Chem., 84, 1936 (1980). 1025

63. T. Ruskov, S. Asenov, I. Spirov, C. Garcia, I. Mönch, A. Graff, R. Kozhuharova, 1026 A. Leonhardt, T. Mühl, M. Ritschel, C. M. Schneider, and S. Groudeva-Zotova, J. 1027 Appl. Phys., 96, 7514 (2004).

64. F. Jaouen, J. Herranz, M. Lefèvre, J. P. Dodelet, U. I Kramm, P. Herrmann, 102 P. Bogdanoff, J. Maruyama, T. Nagaoka, A. Garsuch, J. R. Dahn, T. Olson, 1030 S. Pylypenko, P. Atanassov, and E. Ustinov, Appl. Mater. Interf., 1, 1623 (2009). 1031

65. H. Schulenburg, S. Stankov, V. Schünemann, J. Radnik, I. Dorbandt, S. Fiechter, 1032 P. Bogdanoff, and H. Tributsch, J. Phys. Chem. B, 107, 9034 (2003).

66. K. Artyushkova, S. Levendosky, P. Atanassov, and J. Fulghum, Top. Catal., 46, 2631034 (2007).

67. K. Artyushkova, S. Pylypenko, T. Olson, J. E. Fulghum, and P. Atanassov, Langmuir , 1036 24, 9082 (2008)

68. J. Casanovas, J. M. Ricart, J. Rubio, F. Illas, and J. M. Jimenz-Mateos, J. Am. Chem. 1038 Soc., 118, 8071 (1996)

69. Personal communication with Dr Piotr Zelenay, October 2014. The $\mathrm{H}_{2} \mathrm{O}_{2}$ degradation 1040 protocol in that study involved $100 \mathrm{mg}$ catalyst immersed in $500 \mathrm{ml}$ of $10 \mathrm{wt} \% \mathrm{H}_{2} \mathrm{O}_{2} . \quad 1041$

70. A. Conde, A. B. Cristobal, G. Fuentes, T. Tate, and J. de Damborenea, Surface \& 1042 coatings technology, 201, 3588 (2006)

71. R. Rozada, J. I. Paredes, S. Villar-Rodi Nano Res., 6, 216 (2013)

72. J.-A. Yan, L. Xian, and M. Y. Chou, Phys. Rev. Lett., 103, 086802 (2009).

73. D. Pandey, R. Reifenberger, and R. Piner, Surf. Sci., 602, 1607 (2008).

74. E. J. Kan, Z. Q. Li, J. Yang, and J. G. Hou, J. Am. Chem. Soc., 130, 4224 (2008)

75. Q. Tang, Z. Zhou, and Z. Chen, Nanoscale, 5, 4541 (2013).
007

008

010

011 14 15 017 019 21 22 24 27 028 30 1032 1034
1035 036 037
038 039 041
042 


\section{Queries}

Q1: Table III is not set in this paper, so please check call out Table III for correctness.

Q2: AU: Please provide a digital object identifier (doi) for $\operatorname{Ref}(\mathrm{s}) 18,20,26,34$, and 42. For additional information on doi's please select this link: http://www.doi.org/. If a doi is not available, no other information is needed from you. 